\title{
Axonally Synthesized $\beta$-Actin and GAP-43 Proteins Support Distinct Modes of Axonal Growth
}

\author{
Christopher J. Donnelly, ${ }^{1}$ Michael Park, ${ }^{2}$ Mirela Spillane, ${ }^{3}$ Soonmoon Yoo ${ }^{4}$ Almudena Pacheco,${ }^{2}$ Cynthia Gomes, ${ }^{2}$ \\ Deepika Vuppalanchi, ${ }^{1}$ Marguerite McDonald, ${ }^{5}$ Hak Hee Kim, ${ }^{4}$ Tanuja T. Merianda, ${ }^{2}$ Gianluca Gallo, ${ }^{3}$ \\ and Jeffery L. Twiss ${ }^{2}$ \\ ${ }^{1}$ Department of Biological Sciences, University of Delaware, Newark, Delaware 19716, ${ }^{2}$ Department of Biology, Drexel University, Philadelphia, \\ Pennsylvania 19104, ${ }^{3}$ Department of Neurobiology and Anatomy, Drexel University College of Medicine, Philadelphia, Pennsylvania 19129, ${ }^{4}$ Nemours \\ Biomedical Research, Alfred I. duPont Hospital for Children, Wilmington, Delaware 19803, and ${ }^{5}$ Department of Chemistry and Biochemistry, University of \\ Delaware, Newark, Delaware 19716
}

Increasing evidence points to the importance of local protein synthesis for axonal growth and responses to axotomy, yet there is little insight into the functions of individual locally synthesized proteins. We recently showed that expression of a reporter mRNA with the axonally localizing $\beta$-actin mRNA 3'UTR competes with endogenous $\beta$-actin and GAP-43 mRNAs for binding to ZBP1 and axonal localization in adult sensory neurons (Donnelly et al., 2011). Here, we show that the 3'UTR of GAP-43 mRNA can deplete axons of endogenous $\beta$-actin mRNA. We took advantage of this $3^{\prime}$ UTR competition to address the functions of axonally synthesized $\beta$-actin and GAP-43 proteins. In cultured rat neurons, increasing axonal synthesis of $\beta$-actin protein while decreasing axonal synthesis of GAP-43 protein resulted in short highly branched axons. Decreasing axonal synthesis of $\beta$-actin protein while increasing axonal synthesis of GAP-43 protein resulted in long axons with few branches. siRNA-mediated depletion of overall GAP-43 mRNA from dorsal root ganglia (DRGs) decreased the length of axons, while overall depletion of $\beta$-actin mRNA from DRGs decreased the number of axon branches. These deficits in axon growth could be rescued by transfecting with siRNA-resistant constructs encoding $\beta$-actin or GAP-43 proteins, but only if the mRNAs were targeted for axonal transport. Finally, in ovo electroporation of axonally targeted GAP-43 mRNA increased length and axonally targeted $\beta$-actin mRNA increased branching of sensory axons growing into the chick spinal cord. These studies indicate that axonal translation of $\beta$-actin mRNA supports axon branching and axonal translation of GAP-43 mRNA supports elongating growth.

\section{Introduction}

Polarized cells use mRNA localization to regulate protein content in their subcellular domains (Holt and Bullock, 2009). For neurons, where large distances separate the ends of axons and dendrites from their cell body, localized protein synthesis allows for rapid and autonomous responses to environmental stimuli. RNA profiling studies of neuronal processes have demonstrated hundreds to thousands of localized mRNAs (Willis et al., 2007; Taylor et al., 2009; Zivraj et al., 2010; Gumy et al., 2011; Cajigas et al., 2012). Extracellular stimuli specifically alter the mRNA populations of sensory axons and fibroblast's pseudopodia in vitro (Willis et al., 2007; Mili et al., 2008). The targeting of mRNAs to subcellular locales is a highly regulated process that affects a sub-

\footnotetext{
Received April 7, 2012; revised Nov. 10, 2012; accepted Dec. 10, 2012.

Author contributions: H.K.K., G.G., and J.L.T. designed research; C.J.D., M.P., M.S., S.Y., A.P., C.G., D.V., M.M., T.T.M., and G.G. performed research; S.Y., D.V., H.K.K., and G.G. contributed unpublished reagents/analytic tools; C.J.D., M.P., M.S., A.P., C.G., M.M., and T.T.M. analyzed data; C.J.D., G.G., and J.L.T. wrote the paper.

This work was supported by grants from National Institutes of Health (R01-NS041596 to J.L.T. and R01NS048090 to G.G.), Craig H. Neilsen Foundation, and the Miriam and Sheldon G. Adelson Foundation. C.J.D. was supported by a graduate fellowship from the University of Delaware over a portion of these studies. Antibody to GAP-43 was kindly provided by J.H. Pate Skene, Duke University.

Correspondence should be addressed to Jeffrey L. Twiss, Department of Biology, Drexel University, 3245 Chestnut Street, PISB Room 123, Philadelphia, PA 19104. E-mail: jeff.twiss@drexel.edu.

DOI:10.1523/JNEUROSCI.1722-12.2013

Copyright $\odot 2013$ the authors $\quad 0270-6474 / 13 / 333311-12 \$ 15.00 / 0$
}

stantial portion of a cell's transcriptome. The function of proteins translated from subcellularly localized mRNAs remains unclear. Functional predictions have been based largely on gene ontology and network analyses, but experimental approaches are needed to distinguish functions of proteins synthesized from localized mRNAs versus those synthesized from the corresponding cell body localized mRNAs.

mRNA targeting with subsequent translational control can regulate where and when a new protein is introduced. Some mRNAs are selectively concentrated in presynaptic or postsynaptic compartments (Lyles et al., 2006; Andreassi et al., 2010). Spatial restriction of translation has functional implications. For example, myoinositol monophosphatase $1 \mathrm{mRNA}$ is enriched in sympathetic axons, and blocking its subcellular localization causes axon degeneration (Andreassi et al., 2010). Axotomyinduced translation of axonal importin $\beta 1$ mRNAs generates a retrograde signal for injury responses in the cell body (Hanz et al., 2003; Ben-Tov Perry et al., 2012). However, for $\beta$-actin, only a small fraction of the axonal protein is derived from local translation of its mRNA. The majority of axonal $\beta$-actin protein is derived from mRNA translated in the cell body (Eng et al., 1999; Donnelly et al., 2011). It is appealing to hypothesize that cell body synthesized and axonally synthesized proteins represent different functional pools of $\beta$-actin for the neuron. However, functional studies of the locally generated $\beta$-actin in developing axons have 
produced conflicting results (Leung et al., 2006; Yao et al., 2006; Roche et al., 2009; Sasaki et al., 2010; Cheever et al., 2011; Manns et al., 2012), and the question of what cellular mechanisms locally generated $\beta$-actin protein contribute to in the axon remains unresolved.

We recently showed that the protein products of mRNAs transported into axons by the RNA binding protein ZBP1, including $\beta$-actin mRNA, are needed for peripheral nerve regeneration (Donnelly et al., 2011). In this study, a GFP reporter mRNA with the $3^{\prime}$ UTR of $\beta$-actin competed with endogenous $\beta$-actin and GAP-43 mRNAs for axonal transport (Donnelly et al., 2011). Limited levels of $\mathrm{ZBP} 1$ in adult neurons are the basis of this competition. Here, we have exploited this $3^{\prime} \mathrm{UTR}$ competition to test for functions of the locally translated $\beta$-actin and GAP-43 proteins. We show that $\beta$-actin promotes branching of axons and GAP-43 promotes elongating growth of axons, but only when their mRNAs are targeted to axons for localized translation.

\section{Materials and Methods}

Rodent surgery and primary neuronal cultures. For preparation of cultured dorsal root ganglion (DRG) neurons, L4-L5 DRGs of 175-200 g male Sprague Dawley rats were dissociated and cultured as described previously (Twiss et al., 2000). Dissociated ganglia were plated on glass coverslips or polyethylene terephthalate (PET) membranes that had been precoated with polylysine and laminin.

Dissociated neurons were transfected with plasmid constructs using the AMAXA Nucleofector and Small Cell Number kit (Lonza) with $2 \mu \mathrm{g}$ of each DNA. In some experiments, DRGs were replated $2.5 \mathrm{~d}$ after transfection to analyze the initial stages of growth analogous to injuryconditioned DRG neurons. For this, dissociated DRG cultures were vigorously triturated in DMEM/F12 (Invitrogen), 10\% fetal bovine serum (Gemini), and N1 supplement (Sigma) using a fire-polished Pasteur pipette, and then gently pelleted and replated in the same medium.

For fractionating axons, DRGs were cultured on PET membrane inserts with $3 \mu \mathrm{m}$ diameter pores (BD Falcon) as described previously (Willis et al., 2007). After $20 \mathrm{~h}$ in culture, the axons were isolated; RNA was then isolated from the axonal compartment using an RNAqueousMicro kit (Ambion). Axonal purity was tested by reverse transcription (RT)-PCR for $\beta$-actin, ErbB3, MAP2, GFAP, H1F0, and peripherin RNAs (see below) (Cox et al., 2008; Vuppalanchi et al., 2010).

DNA expression constructs. mRNA segments for expression constructs were generated by RT-PCR using rat DRG RNA as a template. All cloned PCR products were full sequence validated before use. Sequences for PCR primers and fluorescent in situ hybridization (FISH) probes (see below) are available on request. Myristoylated green fluorescent protein $\left(\right.$ GFP $^{\text {myr }}$ ) with the $3^{\prime}$ UTR of rat $\gamma$-actin and $\beta$-actin have been described (Willis et al., 2007). Other $3^{\prime}$ UTR constructs were based on this, with cDNAs cloned into Not1 and Xhol restrictions sites immediately downstream of the GFP ${ }^{\text {myr }}$.

Open reading frame (ORF) constructs were based on the published rat $\beta$-actin $\cdot$ mCherry fusion protein construct with the $3^{\prime}$ UTRs of $\beta$-actin and $\gamma$-actin $\left(\beta\right.$-actin $\cdot \mathrm{mCh}-3^{\prime} \beta$-actin and $\beta$-actin $\cdot \mathrm{mCh}-3^{\prime} \gamma$-actin, respectively) (Donnelly et al., 2011). Amplified GAP-43 ORF was initially cloned into pTOPO vector (Invitrogen). The rat GAP-43 ORF was then subcloned into BsrG1 and Not1 restriction sites of $\mathrm{p} \beta$-actin $\cdot \mathrm{mCh}$ replacing the $\beta$-actin ORF. For generating ORF constructs with different 3'UTRs, PCR-amplified 3'UTRs were subcloned into BamH1 and Mfe 1 restriction sites of the $\beta$-actin $\cdot \mathrm{mCh}$. Myc-tagged $\beta$-actin and GAP-43 ORFs were generated by PCR using primers including the myc tag and 3'ORF sequences.
Depletion of endogenous mRNAs. ON-TARGET siRNAs targeting the 3'UTRs of rat $\beta$-actin mRNA (NM 031144) and GAP-43 mRNA (NM 017195) were purchased from Dharmacon. A nontargeting siRNA sequence (siControl; Dharmacon) was used as a control. Cotransfection with siGlow (Dharmacon) was used to identify siRNA-transfected neurons. Four hours after plating, cultures were transfected with $300 \mathrm{~nm}$ siRNA to 3'UTR of $\beta$-actin or $400 \mathrm{~nm}$ siRNA to the 3'UTR of GAP43. The medium was changed after $24 \mathrm{~h}$. After a total of $2.5 \mathrm{~d}$ in vitro, cultures were replated by trituration and allowed to re-extend processes for an additional $24 \mathrm{~h}$ before analysis of axonal length or RNA levels (see below). RT-PCR was used to determine the effectiveness of the siRNA treatment (see below).

In situ hybridization. Quantitative FISH combined with immunofluorescence (IF) was used to detect axonal mRNAs and proteins in DRG cultures as described previously (Donnelly et al., 2011). Digoxigenin (DIG)-labeled oligonucleotide probes for $\beta$-actin and amphoterin $\mathrm{mR}$ NAs have been published (Willis et al., 2007). Quantification of FISH signals was performed using exposure, postprocessing matched digital images. Images were captured using a Zeiss Axioplan microscope fitted with a Hamamatsu ORCA-ER camera. Images were analyzed using ImageJ (National Institutes of Health; NIH). The following primary antibodies were used for immunodetection: sheep anti-DIG (1:100; Roche), chicken anti-neurofilament (NF) H (1:500; Millipore), chicken antiNFM (1:500; Aves), and rabbit anti-peripherin (1:500; Millipore). Secondary antibodies were donkey anti-sheep-Cy5, donkey anti-chickenFITC, and goat anti-rabbit-FITC (1:200; Jackson ImmunoResearch). Negative controls for these FISH analyses consisted of scrambled DIGlabeled oligonucleotides; images for individual experiments were normalized to the negative control and reported as pixels $/ \mu \mathrm{m}^{2}$ above this threshold level.

Immunoblotting. Axons were isolated from transfected DRG cultures grown on porous membranes as above and then lysed in radioimmunoprecipitation assay buffer. After normalization for protein content by Bradford assay, axonal proteins ( $15 \mu \mathrm{g}$ ) were fractionated on $10 \%$ SDS/ PAGE gels and transferred to PVDF membrane. Blots were then blocked with $5 \%$ nonfat dry milk in Tris-buffered saline plus $0.5 \%$ Tween 20 (TBST) for $1 \mathrm{~h}$. Blots were then probed with mouse 91-E12 anti-GAP43 (1:50,000; Skene et al., 1986) or AC15 anti- $\beta$-actin (1:5000; Sigma) overnight at $4^{\circ} \mathrm{C}$ in blocking buffer. After washing, blots were probed with horseradish peroxidase-conjugated goat anti-mouse (1:1000; Jackson ImmunoResearch) for $1 \mathrm{~h}$ in blocking buffer; then washed in TBST and developed with ECL ${ }^{\text {plus }}$ (GE Biosciences).

Analyses of axonal growth. Axonal morphology was measured using green fluorescent protein (GFP) and immunostaining signals in transfected and/or immunostained DRG cultures as described previously (Donnelly et al., 2011). All analyses were performed by a blinded observer with images of neurons chosen based on expression of transfected reporter proteins and siRNAs. Mean axon length was obtained by measuring the longest axon per neuron using Image (NIH). The number of branches was obtained by manually scoring GFP-positive processes $\geq 25$ 
A
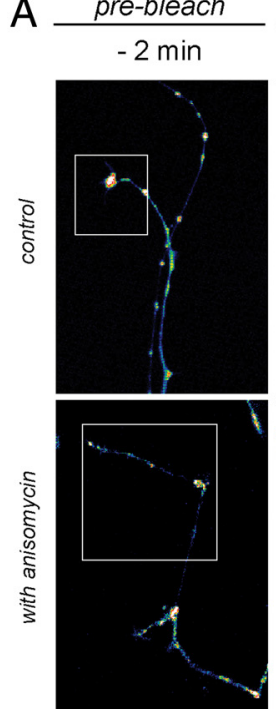

post-bleach

$0 \min$
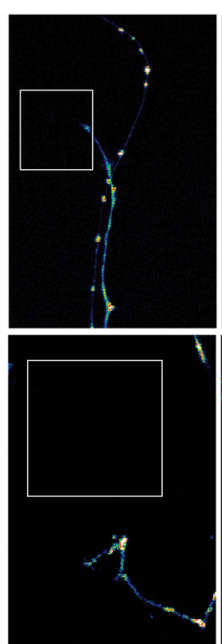

$10 \mathrm{~min}$
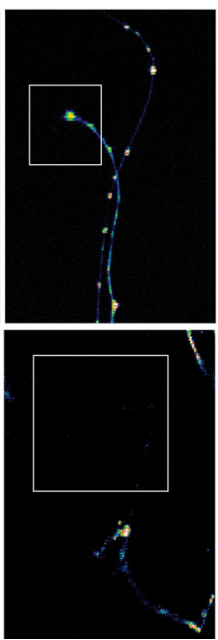

$30 \mathrm{~min}$
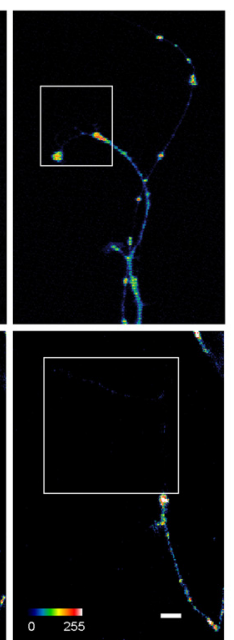

B

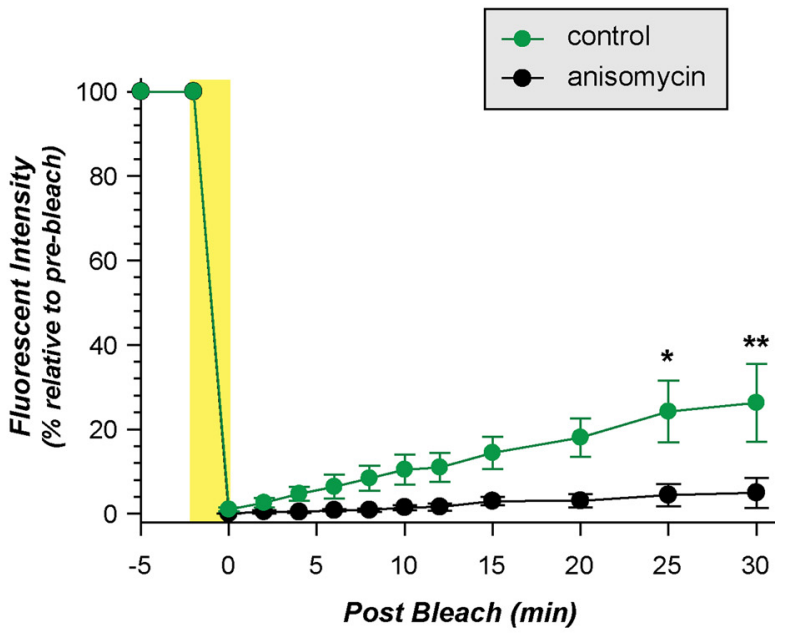

Figure 2. Axonal mRNA localization through heterologous 3'UTR. FRAP analysis of neurons transfected with GFP myr $+3^{\prime}$ UTR of amphoterin mRNA is shown. $A$, Representative time-lapse sequences for prebleach, bleach, and postbleach at indicated intervals for control and anisomycin-treated cultures. The boxed region shows the bleached ROI. GFP intensity is shown as a spectrum as indicated. B, Quantitation of average signal intensity \pm SEM for the bleached ROI from multiple time-lapse sequences normalized to prebleach intensity. The GFP myr ${ }^{\prime}{ }^{\prime}$ Amph shows a protracted recovery from photobleaching that is attenuated by pretreatment with the protein synthesis inhibitor $\left({ }^{*} p \leq 0.05,{ }^{* *} p \leq 0.01\right.$ for indicated time point pairs by two-way ANOVA comparing to $t=$ $0 \mathrm{~min})$. Scale bar, $50 \mu \mathrm{m}$.

$\mu \mathrm{m}$ in length. For filopodia number, GFP-positive, NF + P-negative processes measuring at least one-half the axon diameter were manually scored for at least 30 different processes over at least three different culture preparations.

Fluorescence recovery after photobleaching. To determine the axonal localizing capability for the $3^{\prime} \mathrm{UTR}$ of amphoterin mRNA, dissociated DRG neurons were transfected with $\mathrm{GFP}^{\mathrm{myr}} 3^{\prime}$ Amph constructs and then processed for fluorescence recovery after photobleaching (FRAP) as described previously (Vuppalanchi et al., 2010). Briefly, the terminal axons of cells expressing GFP ${ }^{\mathrm{myr}} 3^{\prime}$ Amph were photobleached with $100 \%$ power of 488 laser using Leica SP2 confocal microscope fitted with an environmental chamber maintained at $37^{\circ} \mathrm{C}, 5 \% \mathrm{CO}_{2}$. The bleached region of interest (ROI) was then monitored for recovery by scanning with $488 \mathrm{~nm}$ laser (7\% power) every $2 \mathrm{~min}$ for $30 \mathrm{~min}$. Fluorescent intensity was normalized to prebleach levels for comparison across multiple experiments. Cultures were pretreated with $50 \mu \mathrm{M}$ anisomycin to test for translational dependence of recovery.

In ovo expression of DNA constructs. In ovo electroporation at embryonic day (E) 3 was used for in vivo expression of $\beta$-actin $\cdot \mathrm{mCh}$ and GAP43 $\cdot$ mCh constructs as previously described (Spillane et al., 2011). Briefly, early DRGs of chick embryos were electroporated at E3, and the embryos were harvested at E7. The spinal cord was acutely dissected from the embryos in its entirety from the first caudal rib, bisected, placed in an imaging dish, and then immediately imaged at either $20 \times$ or $100 \times$ (see Fig. 7A). This allowed us to resolve the extent of axon growth into the caudal spinal cord by DRG axons growing in the dorsal funiculi using a $20 \times$ objective with montage reconstructions, and the details of axonal and growth cone morphology using a $100 \times$ objective. Imaging was performed using an Orca ER camera (Hamamatsu) fitted to a Zeiss $200 \mathrm{M}$ microscope.

Statistical analyses. All statistical analyses were performed with GraphPad Prism statistical software. Tests used are indicated in the appropriate figure legend. $p$ values of $\leq 0.05$ were considered as statistically significant.

\section{Results}

GAP-43's 3' UTR competes with endogenous $\beta$-actin mRNA for axonal localization and attenuates axon outgrowth GAP-43 mRNA has been detected in axons of multiple neuronal types (Willis et al., 2007; Taylor et al., 2009; Gumy et al., 2011).
We previously showed that expression of a GFP reporter carrying the $3^{\prime} \mathrm{UTR}$ of rat $\beta$-actin mRNA competes with endogenous $\beta$-actin and GAP-43 mRNAs for binding to ZBP1 and axonal transport (Donnelly et al., 2011). We reasoned that if this is truly a competition, then the 3'UTR of GAP-43 mRNA should similarly deplete axons of endogenous $\beta$-actin mRNA. To test this possibility, we generated a reporter construct carrying the localization element of GAP-43. DRG neurons expressing a diffusionlimited GFP construct (GFP ${ }^{\text {myr }}$ ) carrying the $3^{\prime}$ UTR of GAP-43 mRNA (GFP ${ }^{\text {myr }} 3^{\prime}$ GAP43) showed decreased levels of endogenous $\beta$-actin mRNA in their axons compared with neurons expressing an empty GFP reporter or a nonlocalizing $\mathrm{GFP}^{\mathrm{myr}} 3^{\prime} \gamma$ actin reporter (Fig. $1 A, B$ ). These data indicate that the $3^{\prime} \mathrm{UTR}$ of GAP-43 mRNA can compete with endogenous $\beta$-actin mRNA for localization into axons.

\section{Increasing axonal targeting of $\beta$-actin and GAP-43 coding} sequence mRNAs alters axonal outgrowth

DRG neurons cultured after an in vivo peripheral axotomy show long, unbranched axons over the first $24 \mathrm{~h}$ in culture compared with neurons from uninjured animals that show short, highly branched axons. Smith and Skene (1997) referred to these morphologies as "elongating" and "arborizing" growth, respectively. Since both GAP-43 and $\beta$-actin mRNAs localize to axons and the 3'UTRs appear to compete for transport into axons, we asked whether the proteins encoded by these axonal transcripts might contribute to these different growth morphologies. We reasoned that targeting the ORFs of $\beta$-actin versus GAP-43 mRNAs into axons in the absence of their UTR competition would allow us to effectively analyze local functions of their encoded proteins. For this, we used the $3^{\prime}$ UTR of amphoterin mRNA to target the $\beta$-actin and GAP-43 ORFs into axons, since our previous studies indicated that axonal amphoterin mRNA levels are not altered by depletion or overexpression of ZBP1 (Donnelly et al., 2011). DRG neurons transfected with GFP ${ }^{\text {myr }}$ containing the $3^{\prime}$ UTR of amphoterin (GFP ${ }^{\text {myr }} 3^{\prime}$ Amph) showed brisk GFP fluorescence in terminal axons (Fig. 2A). After photobleaching, the GFP 
A
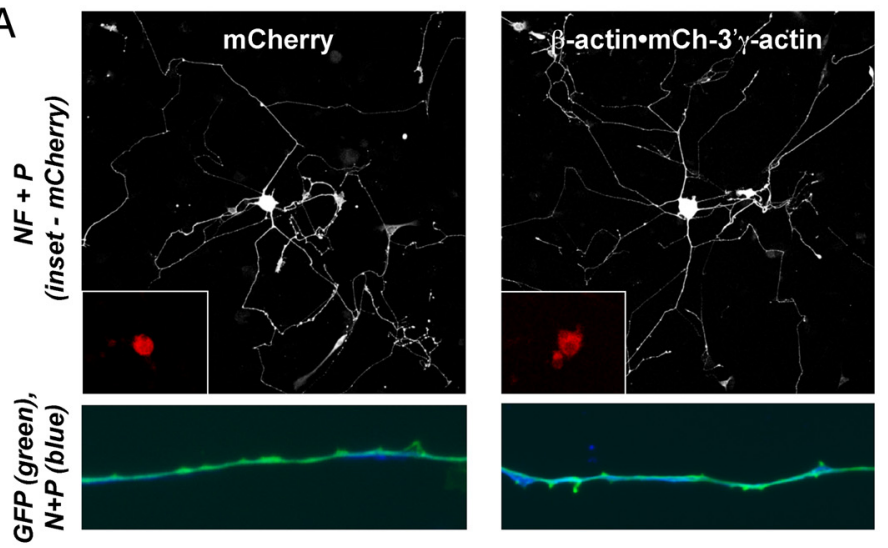

B

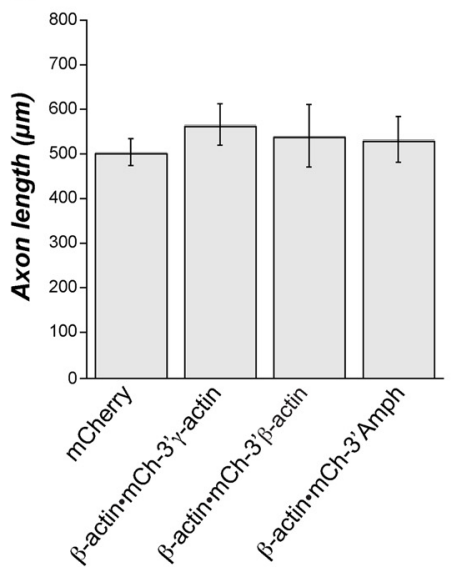

C

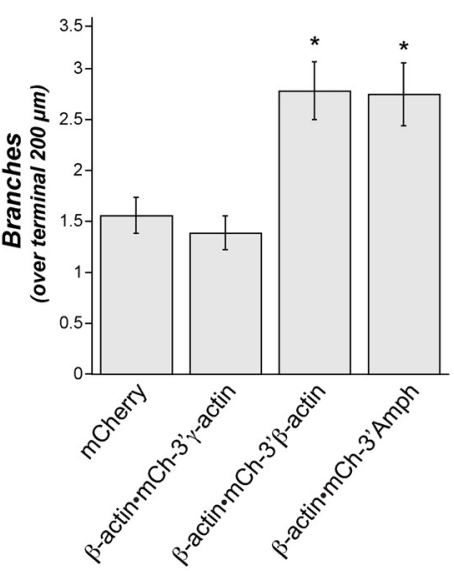

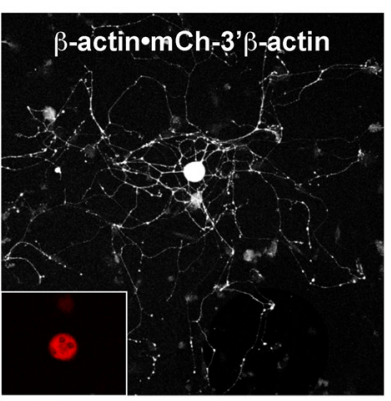

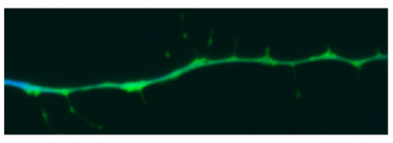

D

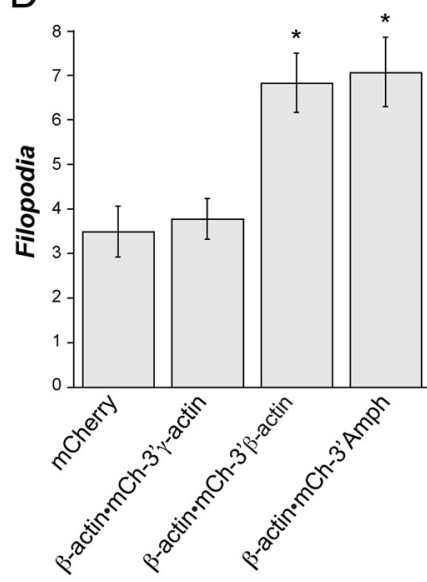

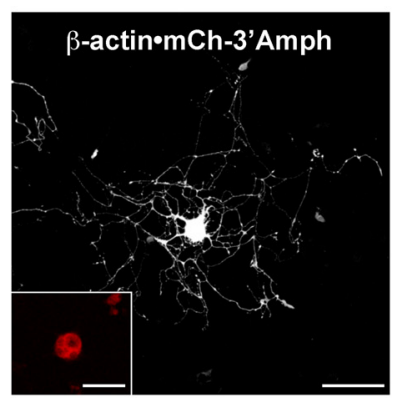
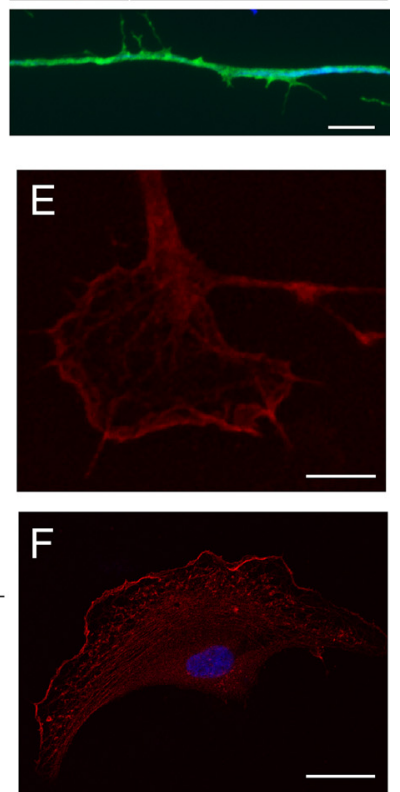

Figure 3. Axonally targeted $\beta$-actin mRNA supports branching growth. $\boldsymbol{A}$, Representative images of naive DRG neurons cotransfected with GFP and mCherry, $\beta$-actin $\cdot \mathrm{mCh}-3^{\prime} \gamma$-actin, $\beta$-actin • $\mathrm{mCh}$-3' $\beta$-actin, or $\beta$-actin • $\mathrm{mCh}$-3'Amph are shown. The upper row shows low-magnification images for NF $+\mathrm{P}$ immunostaining; insets show mCherry signals for the cell bodies. The lower row shows high-magnification images for GFP (green) and N $+\mathrm{P}$ (blue) signals in mid-axon shaft. Note the increase in arborizing growth and filopodia formation for neurons expressing the axonally targeted $\beta$-actin $\cdot \mathrm{mCh}-3^{\prime} \beta$-actin and $\beta$-actin $\cdot \mathrm{mCh}$ - $3^{\prime}$ Amph mRNAs compared with the cell body-restricted $\beta$-actin $\cdot \mathrm{mCh}-3^{\prime} \gamma$-actin and control $\mathrm{mCherry}$. Scale bars: upper row, 100 $\mu \mathrm{m}$, inset $=50 \mu \mathrm{m}$; lower row, $10 \mu \mathrm{m}$. $\boldsymbol{B}-\boldsymbol{D}$, Quantification of indicated growth parameters for neurons transfected as in $\boldsymbol{A}$ are shown. There is no significant change in axon length with transfection of axonally targeted or cell body-restricted $\beta$-actin $\cdot \mathrm{mCh}$ constructs compared with mCherry control $(\boldsymbol{B})$. In contrast, both numbers of axon branches $(\boldsymbol{C})$ and filopodia $(\boldsymbol{D})$ are significantly increased in the cultures expressing $\beta$-actin $\cdot \mathrm{mCh}-3^{\prime} \beta$-actin and $\beta$-actin $\cdot \mathrm{mCh}-3^{\prime}$ Amph $\mathrm{mRNAs}$ compared with $\beta$-actin $\cdot \mathrm{mCh}-3^{\prime} \gamma$-actin and control $\mathrm{mCherry}\left({ }^{*} p \leq 0.05\right.$ for indicated value vs $m$ Cherry and $\beta$-actin $\cdot \mathrm{mCh}-3^{\prime} \boldsymbol{\gamma}$-actin by student's $t$ test). $\boldsymbol{E}-\boldsymbol{F}$, Single optical plane confocal images for mCherry signals (red) in an enlarged growth cone (E) and Schwann cell $(\boldsymbol{F})$ from cultures transfected with $\beta$-actin $\cdot \mathrm{mCh}-3^{\prime}$ Amph are shown. DAPI signals are shown in blue for $\boldsymbol{F}$. Filamentous $\beta$-actin $\cdot \mathrm{mCh}$ signal can be seen both in growth cone and $\mathrm{Schwann}$ cell cytoplasm. The $\beta$-actin $\cdot \mathrm{mCh}$-3' $\gamma$-actin transfected cultures show similar localization for $\beta$-actin $\cdot \mathrm{mCh}$ (data not shown). Scale bars: $\boldsymbol{E}, 5 \mu \mathrm{m} ; \boldsymbol{F}, 10 \mu \mathrm{m}$.

signals in distal axons showed a slow but translation-dependent recovery consistent with localized translation (Fig. $2 A, B$ ). FISH analyses also showed axonal localization of $\mathrm{GFP}^{\mathrm{myr}} 3^{\prime} \mathrm{Amph}$ mRNA (data not shown). Thus, the $3^{\prime} \mathrm{UTR}$ of amphoterin is sufficient for axonal mRNA targeting. Consistent with this, studies below show that amphoterin's 3'UTR can drive the ORFs of GAP-43 and $\beta$-actin mRNAs into axons both in vitro and in vivo (see below).

Since it is clear that both $\beta$-actin and GAP-43 mRNAs localize into axons, the axon can draw from two sources for $\beta$-actin and GAP-43 proteins: axonal transport of proteins generated by translation of their mRNAs in the cell body, and intra-axonal translation of their localized mRNAs. To determine whether axonally generated $\beta$-actin or GAP-43 proteins could alter axonal growth, we generated $\beta$-actin $\cdot \mathrm{mCherry}$ and $\mathrm{GAP}-43 \cdot \mathrm{mCh}$ Crry fusion protein constructs containing the axonally localizing amphoterin $3^{\prime}$ UTR $(\beta$-actin $\cdot \mathrm{mCh}-3^{\prime} \mathrm{Amph}$ and GAP43 $\cdot \mathrm{mCh}-3^{\prime} \mathrm{Amph}$, respectively) or cell body-restricted $\gamma$-actin $3^{\prime} \mathrm{UTR}\left(\beta\right.$-actin $\cdot \mathrm{mCh}-3^{\prime} \gamma$-actin and GAP43 $\cdot \mathrm{mCh}-3^{\prime} \gamma$-actin, respectively). Both $\beta$-actin $\cdot \mathrm{mCh}$ $3^{\prime}$ Amph and $\beta$-actin $\cdot \mathrm{mCh}-3^{\prime} \gamma$-actin transfected neurons showed
mCherry fluorescence in growth cones (Fig. 3E). Filamentous structures could be seen in growth cones and Schwann cells with both $\beta$-actin $\cdot \mathrm{mCh}$ expression constructs (Fig. $3 E, F$ ). The mCherry fluorescence for the GAP43 $\cdot \mathrm{mCh}-3^{\prime} \mathrm{Amph}$ and GAP43 $\cdot \mathrm{mCh}-3^{\prime} \gamma$ actin transfected DRGs was also concentrated in growth cones (Fig. $4 E)$. Thus, these mCherry fusion proteins showed the anticipated subcellular localization in the transfected DRG cultures.

DRGs transfected with the axonally localizing $\beta$-actin $\cdot \mathrm{mCh}$ $3^{\prime} \beta$-actin or $\beta$-actin $\cdot \mathrm{mCh}-3^{\prime}$ Amph showed an increase in axon branch and filopodia numbers but not in axon length compared with mCherry and cell body-restricted $\beta$-actin $\cdot \mathrm{mCh}-3^{\prime} \gamma$-actin transfected neurons (Fig. $3 A-D$ ). DRG neurons transfected with the axonally localizing GAP43 $\cdot \mathrm{mCh}-3$ 'GAP43 or GAP43 $\cdot \mathrm{mCh}-3^{\prime}$ Amph increased axon length but not branching or filopodia compared with neurons expressing the mCherry or the cell body-restricted GAP $43 \cdot \mathrm{mCh}-3^{\prime} \gamma$-actin (Fig. $4 A, C$ ). Expression of the GAP $43 \cdot \mathrm{mCh}-3^{\prime} \mathrm{GAP} 43$ significantly reduced axon branching and filopodia number, but there was no significant effect on these parameters in the GAP $43 \cdot \mathrm{mCh}-3^{\prime} \mathrm{Amph}$ expressing neurons. Neurons expressing the cell body-restricted 

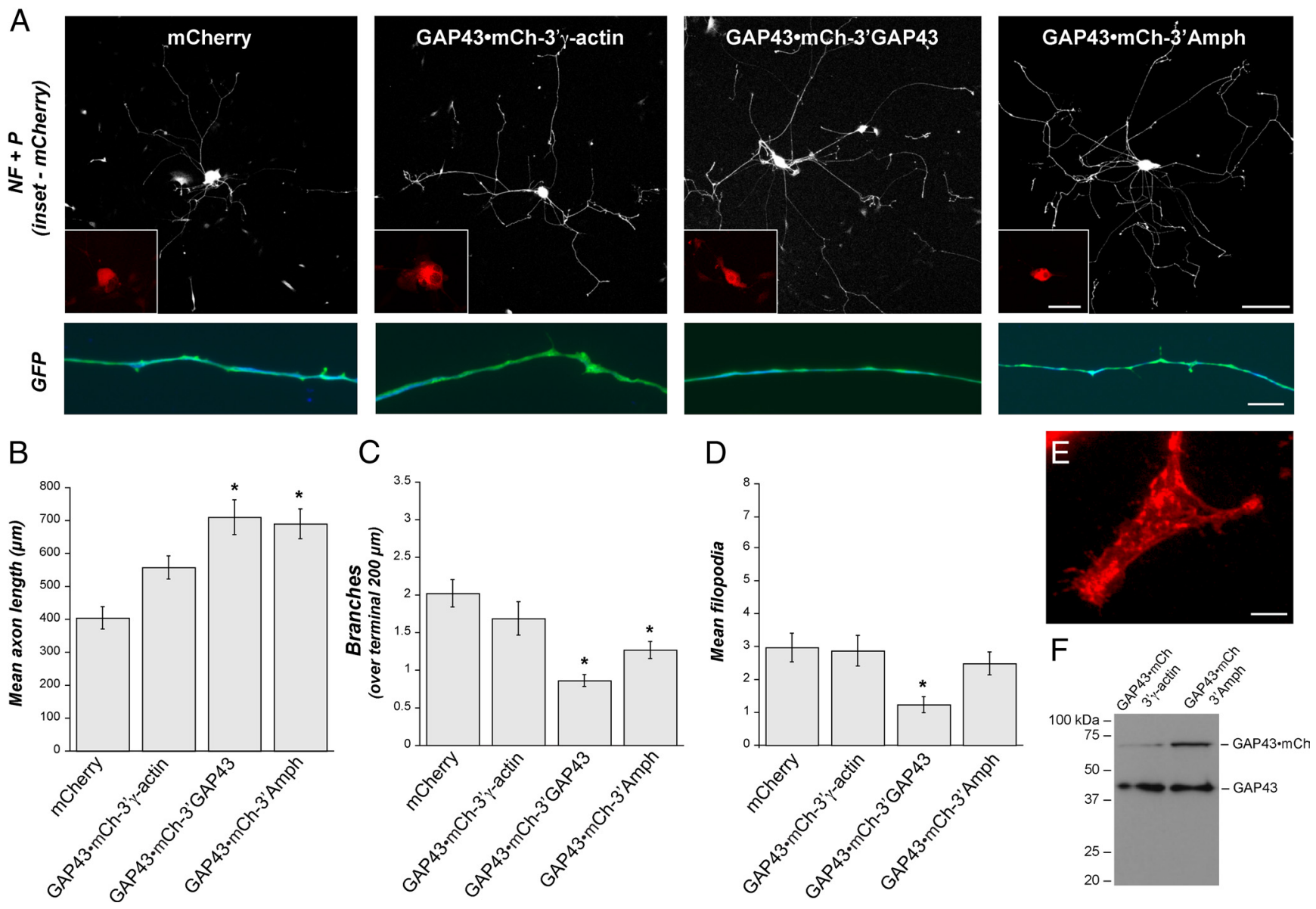

Figure 4. Axonally targeted GAP-43 mRNA supports elongating axonal growth. $A$, Representative images of naive DRG neurons cotransfected with GFP and mCherry, GAP43 • mCh-3' $\gamma$-actin, GAP43 $\cdot \mathrm{mCh}-3^{\prime} \mathrm{GAP} 43$, or GAP43 $\cdot \mathrm{mCh}-3^{\prime}$ Amph are shown. The upper row shows low-magnification images for NF $+\mathrm{P}$ immunostaining; insets show mCherry signals for the cell bodies. The lower row shows high-magnification images for GFP and N + P signals in mid-axon shaft. Note the increase in axon length growth and decreased branching in neurons expressing GAP43 $\cdot \mathrm{mCh}-3^{\prime} \mathrm{GAP} 43$ and GAP43 $\cdot \mathrm{mCh}-3^{\prime}$ Amph mRNAs compared with the GAP43 $\cdot \mathrm{mCh}-3^{\prime} \gamma$-actin and control mCherry. Scale bars: upper row, $200 \mu \mathrm{m}$; inset, $50 \mu \mathrm{m}$; lower row, $10 \mu \mathrm{m}$. $\boldsymbol{B}$ - $\boldsymbol{D}, \mathrm{Quantification}$ of indicated growth parameters for neurons transfected as in $\boldsymbol{A}$ are shown. There is a significant increase in axon length with transfection of axonally targeted GAP43 $\cdot \mathrm{mCh}$ constructs compared with mCherry control and cell body-restricted GAP43 $\cdot \mathrm{mCh}-3^{\prime} \gamma$-actin; the cell body-restricted GAP43 $\cdot \mathrm{mCh}-3^{\prime} \gamma$-actin neurons show increased length but this does not reach significance $(\boldsymbol{B})$. Axon branching $(\boldsymbol{C})$ and filopodia number $(\boldsymbol{D})$ are significantly decreased with expression of GAP43 $\cdot \mathrm{mCh}-3^{\prime} \mathrm{GAP} 43$ compared with mCherry control and GAP43 $\cdot \mathrm{mCh}-3^{\prime} \gamma$-actin, but not with GAP43 $\cdot \mathrm{mCh}-3^{\prime}$ Amph expression ( ${ }^{*} p \leq 0.05$ for indicated value vs mCherry and GAP43 $\cdot \mathrm{mCh}-3^{\prime} \gamma$-actin by student's $t$ test). $\boldsymbol{E}$, Representative image of growth cone in GAP43 $\cdot \mathrm{mCh}-3^{\prime}$ Amphtransfected cultures is shown. The mCherry signal is focally concentrated in the growth cone with focal submembranous appearance. The GAP43 $\cdot \mathrm{mCh}-3^{\prime} \gamma$-actin-transfected cultures show similar growth cone localization for GAP43 - $\mathrm{mCh}$ (data not shown). Scale bar, $1 \mu \mathrm{m}$. $\boldsymbol{F}$, Immunoblot for GAP-43 protein for isolated axons from GAP43 $\cdot \mathrm{mCh}-3^{\prime}$ Amph and GAP43 $\cdot \mathrm{mCh}-3^{\prime} \gamma$-actintransfected cultures is shown. Endogenous GAP-43 protein is comparable between the two conditions, but there is an increased GAP43 $\cdot \mathrm{mCh}$ signal in the axons from cultures transfected with the axonally localizing 3'Amph construct.

GAP43 $\cdot$ mCh-3' $\gamma$-actin did show a small increase in axon length over the mCherry transfected neurons, but this did not reach statistical significance in our studies (Fig. 4B). This small increase is consistent with analyses of neurons cultured from GAP-43 transgenic mice that similarly did not include the $3^{\prime}$ UTR of GAP-43 in the transgene (Bomze et al., 2001).

Immunoblotting of axonal lysates prepared from the transfected DRG cultures showed a clear increase in GAP43 $\cdot \mathrm{mCh}$ protein in axons of the GAP $43 \cdot \mathrm{mCh}-3^{\prime} \mathrm{Amph}$-transfected cultures compared with the GAP43 $\cdot \mathrm{mCh}-3^{\prime} \gamma$-actin-transfected cultures (Fig. 4F). We could not detect the transfected $\beta$ actin $\cdot \mathrm{mCh}$ in these lysates by immunoblotting using anti- $\beta$ actin antibodies. Attempts to visualize the $\beta$-actin $\cdot \mathrm{mCh}$ in these lysates resulted in severe overexposure of the endogenous axonal $\beta$-actin protein bands that obscured any nearby bands (data not shown). This would be entirely consistent with previous work from Roche et al. (2009) showing that locally translated $\beta$-actin does not influence the overall pool of $\beta$-actin in axons. Still, the lack of detectable increase in axonal $\beta$-actin $\cdot \mathrm{mCh}$ with axonal targeting raised concerns about the mechanisms of the altered axonal growth with this construct. Although amphoterin is not transported by ZBP1 (Donnelly et al., 2011), it was possible that introducing the 3'UTR of amphoterin mRNA in these constructs could alter axon growth through other mechanisms. Indeed, quantitative FISH analyses showed depletion of endogenous amphoterin mRNA from axons of neurons transfected with constructs carrying the $3^{\prime}$ UTR of amphoterin (Fig. 5A,B). However, there was no significant change in axon length or branching with expression of the mCh-3'Amph in the DRG neurons compared with control and mCh-3' $\gamma$-actin-transfected DRGs (Fig. 5C,D).

As a further test for potential effects of the exogenous amphoterin 3'UTR on axonal growth, we generated axonally targeted versus cell body-restricted $\beta$-actin $\cdot \mathrm{mCh}$ and $\mathrm{GAP} 43 \cdot \mathrm{mCh}$ expression constructs with naturally occurring Stat $3 \alpha 3^{\prime}$ UTR variants $\left(\beta\right.$-actin $\cdot \mathrm{mCh}-3^{\prime}$ Stat $3^{\text {long }}, \beta$-actin $\cdot \mathrm{mCh}-3^{\prime}$ Stat $3^{\text {short }}$, GAP43 $\mathrm{mCh}-3^{\prime}$ Stat $3^{\text {long }}$, and GAP $43 \cdot \mathrm{mCh}-3^{\prime}$ Stat ${ }^{\text {short }}$, respectively). Dif- 
ferential polyadenylation element usage in Stat $3 \alpha$ gene in DRGs results in a cell bodyrestricted Stat $3 \alpha$ mRNA with a "short" $3^{\prime}$ UTR and an axonally targeted Stat $3 \alpha$ mRNA with a "long" 3'UTR (Ben-Yaakov et al., 2012). GAP43 $\cdot \mathrm{mCh}-3^{\prime}$ 'Stat $3^{\text {long }}$ transfected DRGs showed increased axon length and the GAP $43 \cdot \mathrm{mCh}-3^{\prime}$ Stat $3^{\text {short }}$ transfected DRGs showed no significant differences in axon length compared with control cultures (Fig. 6A-C). Similarly, the $\beta$-actin $\cdot$ mCh-3'Stat $3^{\text {long }}$-transfected DRGs showed increased axon branching and filopodia, but there was no significant change in branching with $\beta$-actin $\cdot \mathrm{mCh}$ $3^{\prime}$ Stat $3^{\text {short }}$ transfection compared with mCherry-transfected DRGs (Fig. 6A, $B, D$, $E)$. Although we cannot exclude that introduction of the $3^{\prime}$ Stat $3 \alpha^{\text {long }}$ constructs alters transport of Stat $3 \alpha$ and other mRNAs, just as we see with the $3^{\prime}$ Amph constructs in Figure 5, the only difference between the axonally targeted $\beta$-actin $\cdot \mathrm{mCh}$ and GAP43 $\cdot \mathrm{mCh}$ mRNAs under these conditions is the ORF RNA sequence. Thus, our data indicate that the ORF mRNA sequences or encoded proteins of the axonally targeted $\beta$-actin and GAP-43 mRNAs account for the differential changes in axon outgrowth seen with the mCherry fusion constructs rather than any indirect effects of the axonally targeting 3'UTRs used here.

Although the $\beta$-actin $\cdot \mathrm{mCh}$ and GAP43 $\cdot \mathrm{mCh}$ proteins both accumulated in growth cones, it was possible that the fusion proteins introduced additional functions to these ORFs. To address this possibility, we generated myc-tagged versions of the $\beta$-actin and GAP-43 ORF constructs $\left(\beta\right.$-actin ${ }^{\text {myc }} 3^{\prime}$ Amph and GAP43 ${ }^{\text {myc }} 3^{\prime}$ Amph, respectively), reasoning that the much smaller myc tag would be much less likely to hinder $\beta$-actin and GAP-43 function than the mCherry polypeptide. Transfection with axonally targeted $\beta$-actin ${ }^{\text {myc }} 3^{\prime} A m p h$ increased axonal branching but not axon length (average branches/distal $200 \mu \mathrm{m}$ axon, $2.7 \pm 0.40$ for $\beta$-actin ${ }^{\text {myc }} 3^{\prime}$ Amph vs $1.34 \pm 0.33$ for control, $p \leq 0.01$ by students $t$ test; average axon length, $401.2 \pm 28.1$ $\mu \mathrm{m}$ for $\beta$-actin ${ }^{\text {myc }^{\prime}}$ 'Amph vs $425.7 \pm 33.8 \mu \mathrm{m}$ for control, $p>$ 0.5 student's $t$ test). The axonally targeted GAP $43^{\text {myc }} 3^{\prime}$ Amph increased axon length but had no effect on axon branch numbers (average axon length, $665.8 \pm 61.4 \mu \mathrm{m}$ for GAP $43^{\text {myc }} 3^{\prime}$ Amph vs $425.7 \pm 33.8 \mu \mathrm{m}$ for control, $p \leq 0.001$ by student's $t$ test; average branches/distal $200 \mu \mathrm{m}$ axon, $1.56 \pm 0.35$ for GAP $43^{\text {myc }} 3^{\prime} \mathrm{Amph}$ vs $1.34 \pm 0.33$ for control, $p>0.5$ by students $t$ test). Thus, the changes in axonal morphology seen with the axonally targeted ORF constructs would be consistent with the introduction of additional GAP-43 and $\beta$-actin proteins into the axons rather than unique effects of the $\mathrm{ORF} \cdot \mathrm{mCh}$ fusion proteins or targeting 3'UTRs.

\section{Axonally targeted $\beta$-actin and GAP-43 mRNAs can} differentially rescue growth deficits from competing UTRs Depleting endogenous mRNAs from axons through the expression of $\mathrm{GFP}^{\mathrm{myr}} 3^{\prime} \beta$-actin or $\mathrm{GFP}^{\mathrm{myr}} 3^{\prime} \mathrm{GAP} 43$ mRNA decreases both the length and branching of axons (Donnelly et al., 2011). Thus, we asked whether the $\beta$-actin or GAP-43 ORF constructs targeted to axons through the $3^{\prime}$ UTR of amphoterin mRNA could rescue these growth deficits seen with expression of $\mathrm{GFP}^{\text {myr }} 3^{\prime} \beta$-actin or GFP ${ }^{\mathrm{myr}} 3^{\prime} \mathrm{GAP}-43$ (Fig. $7 A$ ). Neurons cotransfected with $\mathrm{GFP}^{\mathrm{myr}} 3^{\prime} \beta$-actin plus cell body-restricted $\beta$-actin $\cdot \mathrm{mCh}-3^{\prime} \gamma$-actin showed decreased axon length and branching compared to those transfected with $\mathrm{GFP}^{\mathrm{myr}} 3^{\prime} \gamma$-actin plus $\beta$-actin $\cdot$ mCh-3' $\gamma$-actin (Fig. $7 B$ ). Cotransfecting with axonally localizing $\beta$-actin $\cdot \mathrm{mCh}-3^{\prime} \mathrm{Amph}$ rescued the axon branching deficit in $\mathrm{GFP}^{\mathrm{myr}} 3^{\prime} \beta$-actin-expressing neurons but had no significant effect on axon length; $\beta$-actin $\cdot \mathrm{mCh}-3^{\prime} \mathrm{Amph}$ also increased axon branching in the GFP ${ }^{\mathrm{myr}} 3^{\prime} \gamma$-actinexpressing neurons (Fig. $7 B$ ). The nonlocalizing $\beta$-actin $\cdot \mathrm{mCh}$ $3^{\prime} \gamma$-actin did not significantly affect axon length or branching in the $\mathrm{GFP}^{\mathrm{myr}} 3^{\prime} \beta$-actin-expressing cultures (Fig. $7 B$ ). These data indicate that the axonally generated $\beta$-actin protein contributes to arborizing axon growth rather than the elongating axon growth that Smith and Skene (1997) showed is characteristic of injury-conditioned neurons.

We next asked whether cotransfecting GAP43 $\cdot \mathrm{mCh}-3^{\prime} \mathrm{Amph}$ might rescue axonal growth deficits in neurons expressing GFP $^{\text {myr }} 3^{\prime}$ GAP43. Neurons cotransfected with GFP ${ }^{\text {myr }} 3^{\prime}$ GAP43 plus control cell body-restricted GAP $43 \cdot \mathrm{mCh}-3^{\prime} \gamma$-actin showed decreased axon length compared to those transfected with $\mathrm{GFP}^{\mathrm{myr}} 3^{\prime} \gamma$-actin plus GAP43 $\cdot \mathrm{mCh}-3^{\prime} \gamma$-actin (Fig. $7 C$ ). Cotransfecting with the axonally localizing GAP43 $\cdot \mathrm{mCh}$ $3^{\prime}$ Amph fully rescued axon length deficit in the GFP ${ }^{\text {myr }} 3^{\prime}$ GAP43expressing neurons but had no significant effect on axon branching; GAP43 $\cdot \mathrm{mCh}-3^{\prime} \mathrm{Amph}$ also significantly increased axon length in the $\mathrm{GFP}^{\mathrm{myr}} 3^{\prime} \gamma$-actin-expressing neurons (Fig. $7 C)$. Thus, consistent with the overexpression of axonally targeted ORFs above, the axonally generated GAP-43 protein appears to support elongating axonal growth rather than the arborizing growth that Smith and Skene (1997) showed is characteristic of naive DRG neurons. In contrast to Figure $1 A$, we did not see a significant change in branch number when the GAP $43 \cdot \mathrm{mCh}$ constructs were cotransfected into 
A

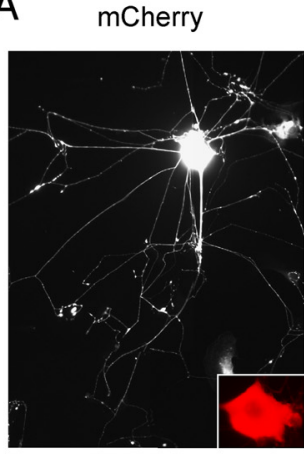

B

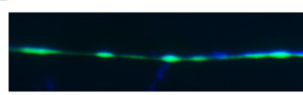

C

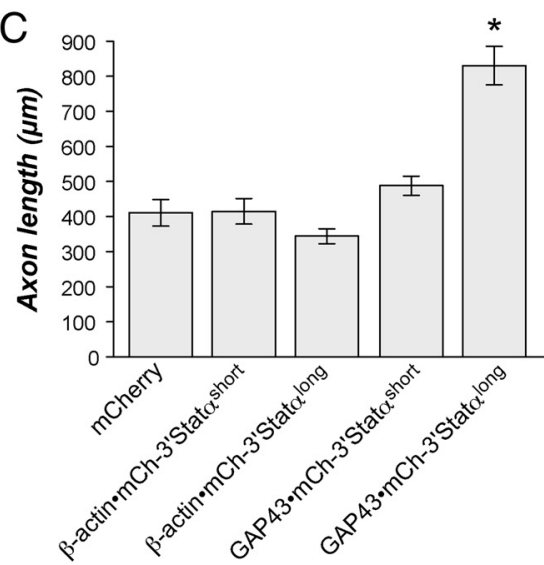

$\beta$-actin॰mCh-

3'Statashort

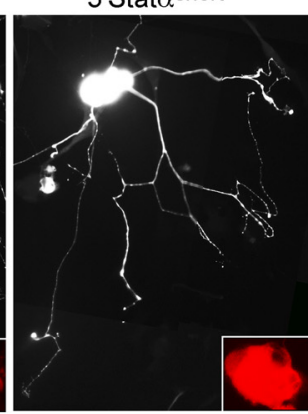

$\beta$-actin•mCh-

3'Statalong

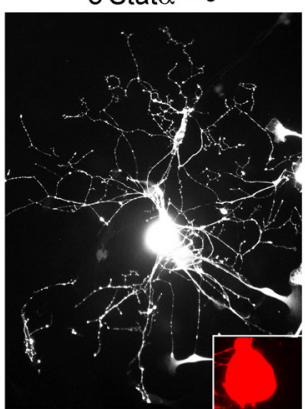

GAP43 $\cdot \mathrm{mCh}$ 3'Statashort

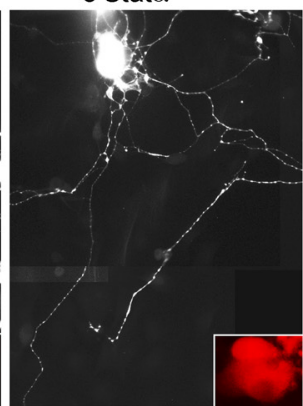

GAP43 $\cdot \mathrm{mCh}$ -

3'Statolong

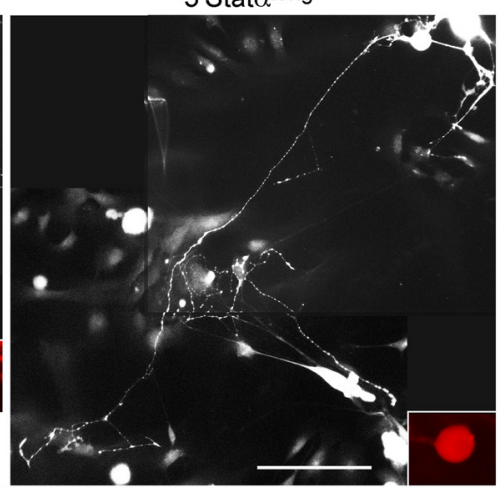

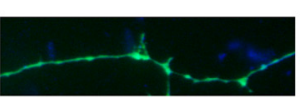

D

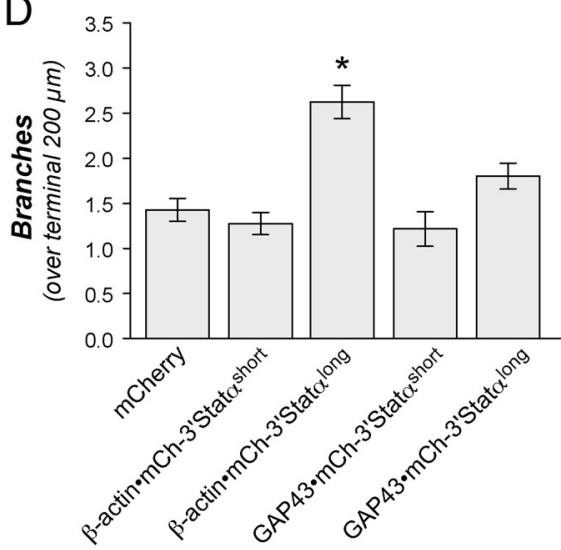

E

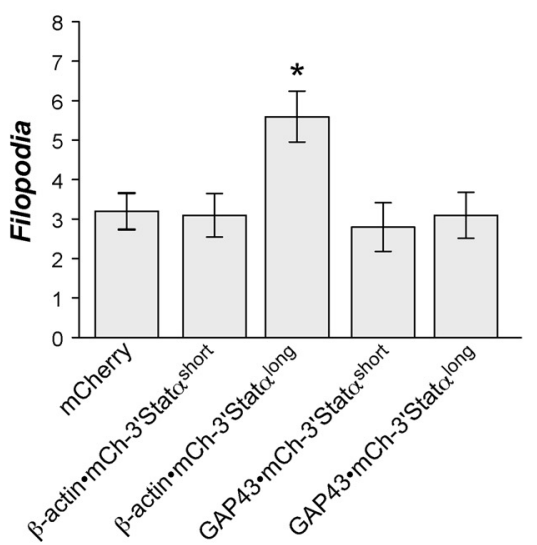

Figure 6. Targeting $\beta$-actin and GAP-43 mRNAs into axons using the STAT3 $\alpha 3^{\prime}$ UTR selectively modulates axonal growth phenotypes. $\boldsymbol{A}$, Representative images of naive DRG neurons cotransfected with GFP and $\mathrm{mCherry}$, cell body-restricted $\beta$-actin $\cdot \mathrm{mCh}-3^{\prime}$ Stat $3 \alpha^{\text {short }}$ or GAP43 $\cdot \mathrm{mCh}-3^{\prime}$ Stat $3 \alpha^{\text {short }}$, or axonally localizing $\beta$-actin $\cdot \mathrm{mCh}-3^{\prime}$ Stat $3 \alpha^{\text {long }}$ or GAP43 $\cdot \mathrm{mCh}$ $3^{\prime}$ Stat $3 \alpha^{\text {long }}$ constructs are shown. NF $+\mathrm{P}$ immunostaining is shown in $A$, and $\mathrm{mCherry}$ signal for the cell bodies is shown in the insets. Neurons expressing the axonally targeted GAP43 $\cdot \mathrm{mCh}$ $3^{\prime}$ Stat $3 \alpha^{\text {long }} \mathrm{mRNA}$ require montage images to capture full axon projection. Scale bar, $100 \mu \mathrm{m}$. B, Representative high-magnification images for GFP (green) and NF + P signals (blue) along mid-axon shaft for neurons transfected as in $\boldsymbol{A}$ are shown. Scale bar, $10 \mu \mathrm{m}$. $\boldsymbol{C}-\boldsymbol{E}$, Quantification of indicated growth parameters for neurons transfected as in $\boldsymbol{A}$ are shown. There is a significant increase in axon length with transfection of axonally targeted GAP43 $\cdot \mathrm{mCh}-3^{\prime}$ Stat $3 \alpha^{\text {long }}$ transfection compared with $\mathrm{mCherry}, \mathrm{GAP} 43 \cdot \mathrm{mCh}-3^{\prime}$ Stat $3 \alpha^{\text {short }}, \beta$-actin $\cdot \mathrm{mCh}-3^{\prime}$ Stat $3 \alpha^{\text {long }}$, and $\beta$-actin $\cdot \mathrm{mCh}-3^{\prime}$ Stat $3 \alpha^{\text {short }}$ transfections $(\boldsymbol{C})$. Axon branching (D) and filopodia $(\boldsymbol{E})$ are significantly increased with expression of $\beta$-actin $\cdot \mathrm{mCh}-3^{\prime}$ Stat $3 \alpha^{\text {long }}$ transfection compared with $\mathrm{mCherry,}$ GAP43 $\cdot \mathrm{mCh}-3^{\prime}$ Stat3 $\alpha^{\text {short }}, \mathrm{GAP} 43 \cdot \mathrm{mCh}-3^{\prime}$ Stat3 $\alpha^{\text {long }}$, and $\beta$-actin $\cdot \mathrm{mCh}-3^{\prime}$ Stat $3 \alpha^{\text {short }}$ transfections ( ${ }^{*} p \leq 0.05$ for indicated value vs mCherry and GAP43 $\cdot \mathrm{mCh}-3^{\prime} \gamma$-actin by student's $t$ test).

$\mathrm{GFP}^{\mathrm{myr}} 3^{\prime} \mathrm{GAP} 43$-expressing neurons. The reason for this discrepancy is not clear.

\section{Axonally localizing $\beta$-actin and GAP-43 ORFs rescue axonal growth deficits seen with knockdown of endogenous $\boldsymbol{\beta}$-actin and GAP-43 mRNAs}

Since the axonally targeted $\beta$-actin and GAP-43 ORFs rescued growth deficits in neurons depleted of axonal $\beta$-actin and GAP-43 mRNAs, we asked whether they might also rescue potential growth deficits seen with overall depletion of $\beta$-actin and GAP-43 mRNAs. For this, we cotransfected neurons with siRNAs targeting 3'UTR of $\beta$-actin or GAP-43 mRNAs and axonally targeted or cell bodyrestricted $\beta$-actin or GAP-43 ORF constructs (Fig. $8 A$ ). The $3^{\prime} \mathrm{UTR}$ targeted siRNAs showed $\sim 70 \%$ depletion of endogenous $\beta$-actin and GAP-43 mRNAs (Fig. 8B). Depletion of $\beta$-actin mRNA decreased axonal branching but did not affect axon length (Fig. 8C). This deficit in branching was rescued by cotransfection with the axonally localizing $\beta$-actin $\cdot \mathrm{mCh}-3^{\prime}$ Amph but not the cell bodyrestricted $\beta$-actin $\cdot \mathrm{mCh}-3^{\prime} \gamma$-actin constructs (Fig. $8 C$ ).

DRG cultures depleted of GAP-43 mRNA showed overall shorter axons (Fig. 8D). This axon length deficit was fully rescued by cotransfection with the axonally localizing GAP43 $\cdot \mathrm{mCh}$ $3^{\prime}$ Amph but not the cell body-restricted GAP43 $\cdot \mathrm{mCh}-3^{\prime} \gamma$-actin constructs (Fig. $8 D$ ). Both the siRNA knockdown of endogenous $\beta$-actin and GAP-43 mRNAs and the rescue experiments are consistent with the axonally synthesized $\beta$-actin protein supporting the arborizing growth of axons and the axonally synthesized GAP-43 protein supporting the elongating growth of axons.

\section{Effects of in vivo over expression of axonally targeted $\beta$-actin} and GAP-43

To determine whether the effects of mRNAs targeted into axons using the amphoterin $3^{\prime}$ UTR observed in vitro would be recapitulated in vivo, we took advantage of a recently developed system for in ovo gene expression in embryonic chicken DRG neurons (Fig. 9A) (Spillane et al., 2011). Four days after the in ovo electroporation at E3, DRG axons are the only structures expressing fluorescent reporters in the caudal portions of spinal cord. We have recently shown that GFP ${ }^{\text {myr }}$ mRNA targeted into DRG axons in ovo using the $3^{\prime} \mathrm{UTR}$ of $\beta$-actin is locally translated in the embryonic spinal cord (Spillane et al., 2012). DRG expression of axonally targeted $\beta$-actin $\cdot \mathrm{mCh}-3^{\prime}$ Amph increased the number 
A

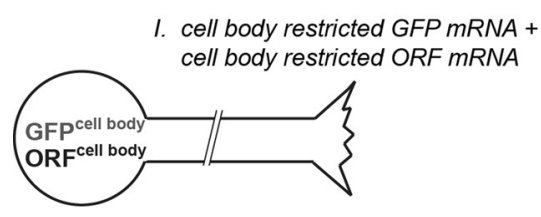

II. cell body restricted GFP mRNA + axonal ORF mRNA

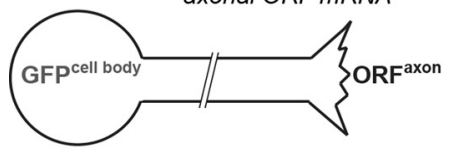

III. axonal GFP mRNA + cell body restricted ORF $M R N A$
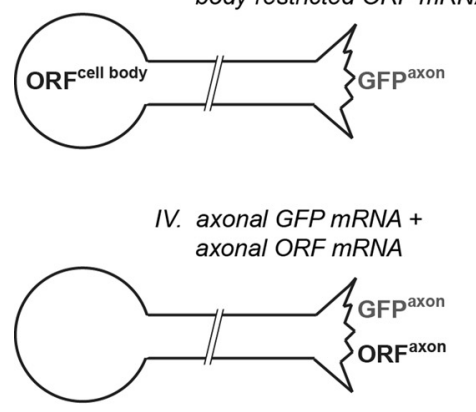

B

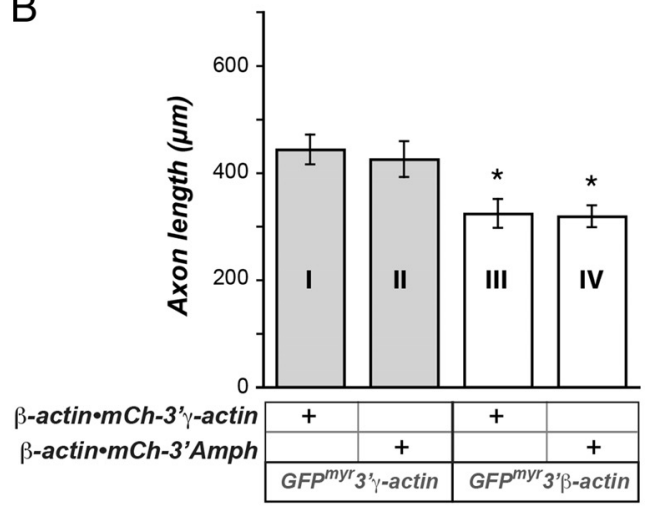

C

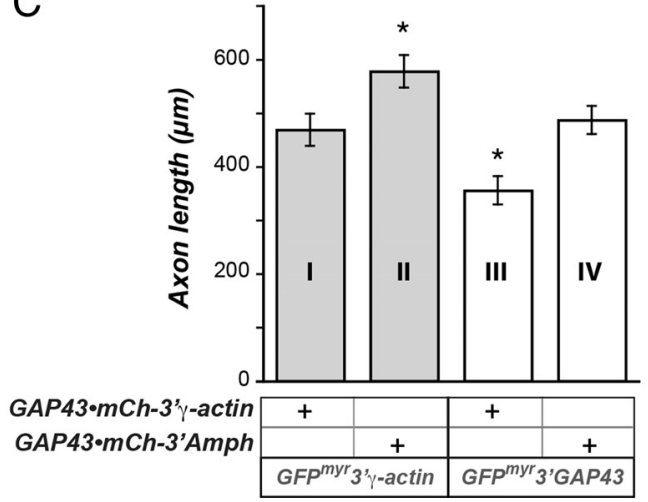

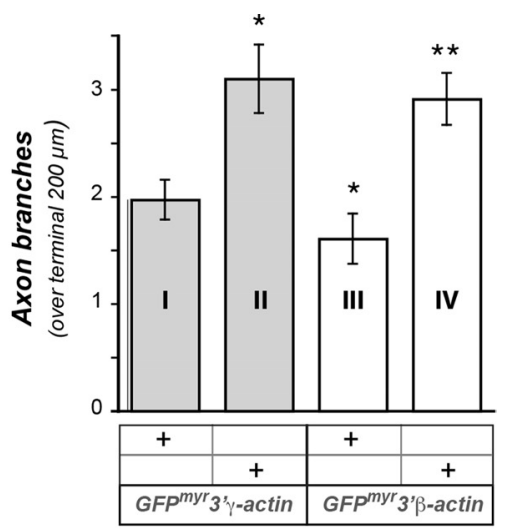

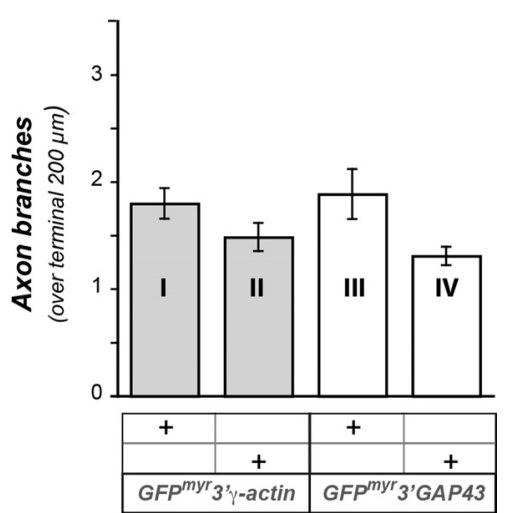

Figure 7. Axonally targeted $\beta$-actin and GAP43 mRNAs rescue selective axonal growth deficits with $3^{\prime}$ UTR competition. $A$, Schematic for the experimental paradigms used to introduce cell body restricted versus axonally targeted and cell body restricted versus axonally targeted ORF constructs. Cell body is shown on left and axon with growth cone on right. Experimental conditions are numbered for reference to data columns in $\boldsymbol{B}$ and $\boldsymbol{C}$. $\boldsymbol{B}$, Expression of GFP ${ }^{\text {myr }} 3^{\prime} \beta$-actin significantly decreased axonal length and branching (columns I vs III). The deficit in branching was rescued by cotransfection with axonally targeted $\beta$-actin $\cdot \mathrm{mCh}-3^{\prime}$ Amph, but this has no effect on axon length (columns IV vs I). Consistent with the data in Figure 3 , the axonally targeted $\beta$-actin $\cdot \mathrm{mCh}$ $3^{\prime}$ Amph also increased axon branching in cells expressing the cell body-restricted GFP ${ }^{\text {myr }} 3^{\prime} \gamma$-actin, but had no effect on overall axon length (columns II vs I). C, Expression of GFP myr 3 ' GAP43 significantly decreased axonal length and branching (columns I vs III). The deficit in axonal length but not branching was rescued by cotransfection with axonally targeted GAP43 • $\mathrm{mCh}-3^{\prime}$ Amph (columns IV vs I). The axonally targeted GAP43 $\cdot \mathrm{mCh}-3^{\prime}$ Amph also increased axon length in cultures expressing the cell body-restricted GFP ${ }^{\text {myr }} 3^{\prime}$ GAP43, but had no effect on overall axon length (columns II vs I). Though there is some variability in branch numbers with GAP43 $\cdot \mathrm{mCh}-3^{\prime}$ Amph expression, this did not reach statistical significance $\left(^{*} p \leq 0.05\right.$, ${ }^{* *} p \leq 0.01$ for indicated value vs column I by ANOVA).

of axonal filopodia relative to both axonally targeted $\mathrm{mCh}$ $3^{\prime}$ Amph and cell body-restricted $\beta$-actin $\cdot \mathrm{mCh}-3^{\prime} \gamma$-actin (Fig. $9 B, C)$. Similarly, expression of $\beta$-actin $\cdot \mathrm{mCh}-3^{\prime}$ Amph also increased the number of axons exhibiting one or more branches and mean number of branches per axon (Fig. 9D,E). Expression of axonally targeted GAP43 $\cdot \mathrm{mCh}-3^{\prime}$ Amph increased the distance that the front of axons extended into the caudal spinal cord relative to the axonally targeted $\mathrm{mCh}-3^{\prime} \mathrm{Amph}$ and cell bodyrestricted GAP43 $\cdot \mathrm{mCh}-3^{\prime} \gamma$-actin (Fig. 9F). Expression of axonally targeted GAP $43 \cdot \mathrm{mCh}-3^{\prime}$ Amph did not alter the number of axonal filopodia (data not shown) or the number of branches per axon (data not shown). These results indicate that in the context of the developing chick spinal cord, axonally synthesized $\beta$-actin protein increases branching of axons and axonally synthesized GAP-43 protein increases axon elongation similar to what we observed in vitro using adult rat DRG neurons.

\section{Discussion}

Peripheral nerve injury triggers a shift in neuronal gene expression programs, turning on expression of genes needed for axon regeneration and turning off expression of genes needed for neuronal function and maintenance (Hoffman, 2010). This shift in gene expression contributes to the rapid, elongating axonal growth that is seen when injury-conditioned neurons are placed in culture (Smith and Skene, 1997), and recent work indicates that signals retrogradely transported from the axon in vivo likely drive this change in gene expression after axotomy (Michaelevski et al., 2010; Ben-Yaakov et al., 2012; Ben-Tov Perry et al., 2012). The robust increase in intra-axonal protein synthesis seen in neurons cultured from injury-conditioned animals (Willis et al., 2005) suggests that localized protein synthesis also contributes to the rapid axonal outgrowth of conditioned neurons. Although we recently showed that axonal transport of ZBP1 cargo mRNAs, including $\beta$-actin and GAP-43 mRNAs, contribute to peripheral nervous system axon regeneration (Donnelly et al., 2011), there have been no data directly linking axonal growth to the functions of individual axonally synthesized proteins. The data presented here show that axonally synthesized $\beta$-actin increases filopodia formation and branching of axons and the axonally synthesized GAP-43 protein increases axon length. These phenotypic changes with overexpression of axonally targeted $\beta$-actin and GAP-43 mRNAs are seen both in cultured rat DRG neurons and in chick DRG neurons in the developing spinal cord in vivo. Filopodia are cellular protrusions strictly dependent on actin filaments enriched in $\beta$-actin protein. The formation of axonal filopodia is the first step in axon branching (Gallo, 2011) and signals that promote formation of axonal filopodia also promote axon 
A

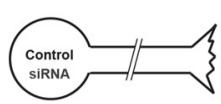

I. siRNA + control

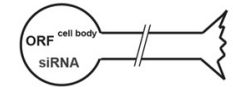

11. $\operatorname{siRNA}+$ cell body restricted ORF MRNA

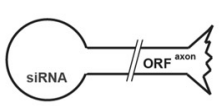

III. SiRNA + axonally localizing ORF MRNA
C

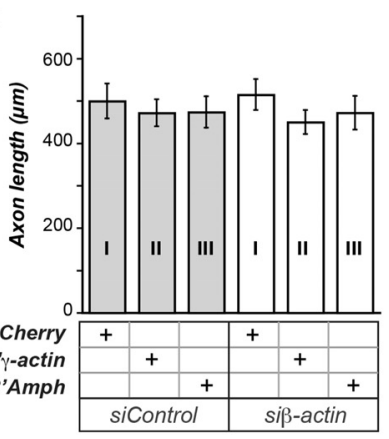

$\beta$-actin-mCh-3' $\gamma$-actin $\beta$-actin॰mCh-3'Amph

D

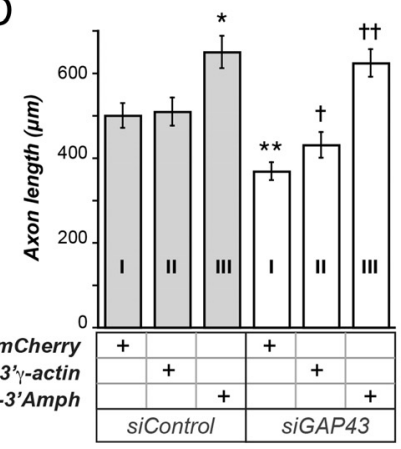

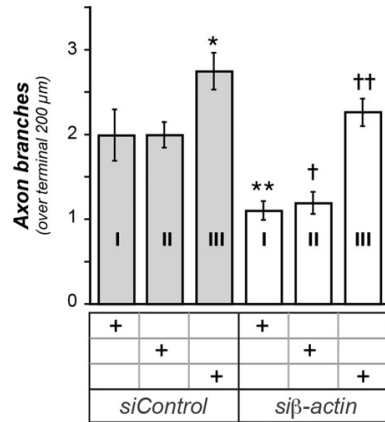

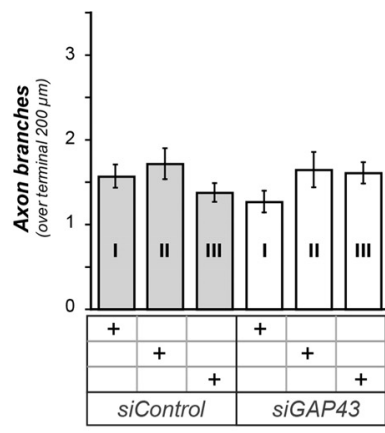

Figure 8. Exogenous axonal $\beta$-actin and GAP-43 mRNAs rescue growth deficits seen in overall depletion of endogenous $\beta$-actin and GAP-43 mRNAs. $A$, Schematic for the experimental paradigms used to introduce cell body restricted versus axonally targeted into DRG cultures depleted of endogenous $\beta$-actin or GAP-43 mRNAs using siRNAs targeting $\beta$-actin or GAP-43 3'UTRs (si $\beta$-actin and siGAP43). A nontargeting siRNA (siControl) was used to control for off-target effects of si $\beta$-actin and siGAP43. Experimental conditions are numbered for reference to data columns in $\boldsymbol{C}$ and $\boldsymbol{D}$. $\boldsymbol{B}$, Representative RT-PCR analyses for mRNAs (endogenous and transfected) in cultures siControl-, si $\beta$-actin-, and siGAP43-transfected cultures. ORF constructs for the si $\beta$-actin series consisted of the $\beta$-actin - mCh and those for the siGAP43 series consisted of GAP43 - mCh. Amplification of GAPDH shows relatively equivalent loading of RNA between samples and the no-RT lanes show no amplification products. The 3'UTR targeted si3' $\beta$-actin and si3'GAP43 specifically decreased levels of endogenous $\beta$-actin and GAP-43 mRNAs, respectively, but had no effect on mCherry, $\beta$-actin $\cdot \mathrm{mCh}$, or GAP43 $\cdot \mathrm{mCh}$ mRNAs. C, si $\beta$-actin transfection compared with siControl caused a significant reduction in axon branching in the mCherry cotransfected cultures (column I). This reduction in axon branching was rescued by cotransfection with axonally targeted $\beta$-actin $\cdot \mathrm{mCh}-3^{\prime}$ Amph but not with the cell body-restricted $\beta$-actin $\cdot \mathrm{mCh}-3^{\prime} \gamma$-actin (column III vs I). The axonally targeted $\beta$-actin $\cdot \mathrm{mCh}$-3'Amph also significantly increased branching in cultures transfected with the siControl, but the cell body-restricted axonally targeted $\beta$-actin $\cdot \mathrm{mCh}$ - $3^{\prime} \gamma$-actin was without effect. The si $\beta$-actin transfection has no significant effect on axon length regardless of cotransfecting axonally targeted or cell body-restricted $\beta$-actin $\cdot \mathrm{m} C \mathrm{C}$. $\boldsymbol{D}$, siGAP43 transfection compared with siControl caused a significant reduction in axon length in the mCherry cotransfected cultures (column I). There was no significant effect on axon branching. This decrease in axon length was completely rescued by cotransfection with axonally targeted GAP43 • mCh-3'Amph, and the axonally targeted GAP43 • mCh-3'Amph increased axon length in siControl-transfected cultures (column III vs I). The cell body-restricted GAP43 • mCh-3' $\gamma$-actin increased axon length in the GAP43 depleted cultures but did not provide a full rescue (column II vs I). $\left({ }^{*} p \leq 0.05\right.$, ${ }^{* *} p \leq 0.01$ for indicated column vs column I for siControl, ${ }^{\dagger} p \leq 0.05$ and ${ }^{+t} p \leq 0.01$ for indicated column vs si $\beta$-actin or siGAP43 column I).

branching (Ketschek and Gallo, 2010). Nerve growth factor induces axonal protein synthesis-dependent axon branching from embryonic chick DRG axons, and the intra-axonal translation of mRNAs for the actin regulatory proteins Arp 2, cortactin, and WAVE1 has been linked to filopodia and branch formation (Spillane et al., 2012). While it remains to be addressed how axonally synthesized $\beta$-actin contributes to the formation of filopodia, the finding that axonally synthesized $\beta$-actin promotes formation of filopodia and branches reveals a specific role for the axonal synthesis of $\beta$-actin.

Several studies in developing neurons indicate that translation of axonal $\beta$-actin mRNA is important for growth cone guidance and motility (Zhang et al., 2001; Zheng et al., 2001; Leung et al., 2006; Sasaki et al., 2010). Additionally, work in fibroblasts has shown that localized synthesis of $\beta$-actin is needed for directional motility (Shestakova et al., 2001). However, Roche et al. (2009) questioned the role of axonally synthesized $\beta$-actin, since they saw no effects on growth of developing axons when axonal translation was blocked. Moreover, mice with a motor neuron-specific knock-out of the $\beta$-actin gene showed normal developmental and regenerative growth of axons (Cheever et al., 2011). Subsequent deletion of $\beta$-actin gene in cortical neurons showed altered axonal growth in the corpus callosum, but no abnormalities in axonal growth of cultured neurons. However, there was a com- pensatory increase in expression of other actin genes in these mice (Cheever et al., 2012). Though $\gamma$-actin apparently does not localize, potential localization of other actin mRNAs was not addressed in these knock-out mice. Moreover, the above studies did not attempt to introduce more of the localizing $\beta$-actin mRNA as we have done here. Expression of the $\beta$-actin $\cdot \mathrm{mCh}$ 3'Amph clearly increased branching of axons, both in cultured adult DRG neurons and in developing DRG axons extending in the spinal cord. The growth deficits seen with overall depletion of $\beta$-actin mRNA and selective depletion of axonal $\beta$-actin mRNA were also rescued by the $\beta$-actin $\cdot \mathrm{mCh}$ construct, but only when the mRNA was targeted to axons. These studies emphasize that axonally generated $\beta$-actin alters axon growth both in cultured neurons and in vivo. It should be noted that Roche et al. (2009) only analyzed growth cone motility and not branching of axons. Similarly, although the study by Cheever et al. (2011) qualitatively did not find overbranching of motoneuron axons as a possible consequence of guidance defects, these authors did not report quantitative analysis of axon branching and there does appear to be decreased branching in their published images (Cheever et al., 2011, their Fig. 3.). It will thus be of interest to revisit those $\beta$-actin knock-out mice in future studies and determine whether there are deficits in the branching of motoneuron axons. 


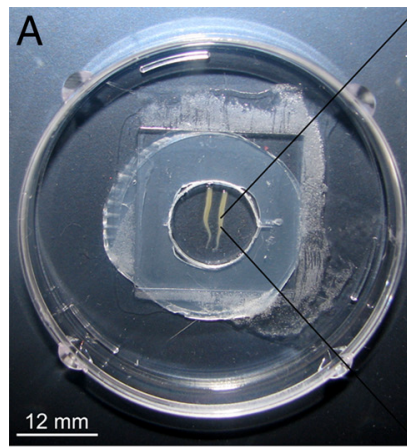

C

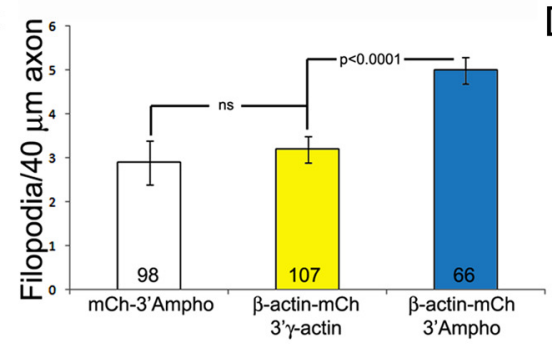

F

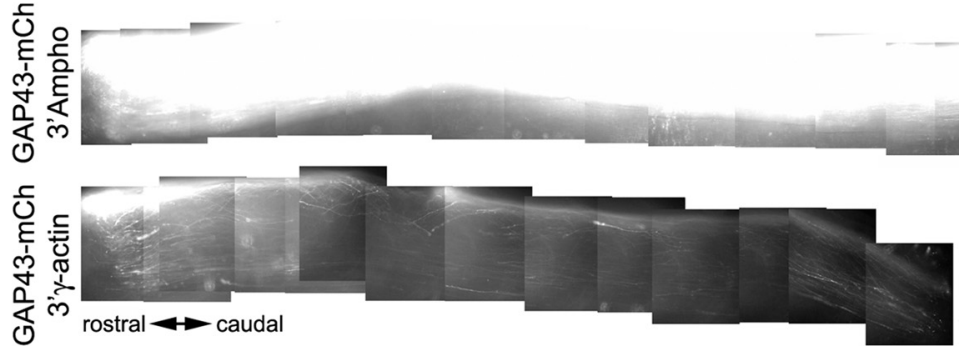

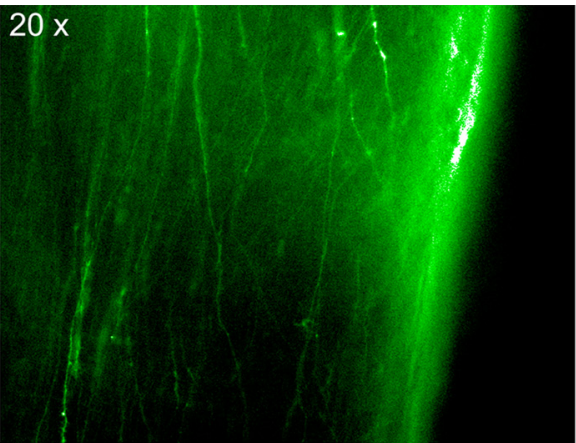

D

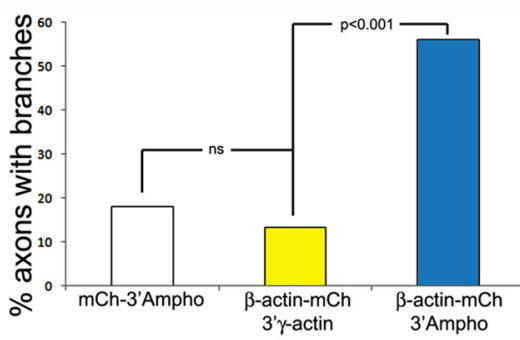

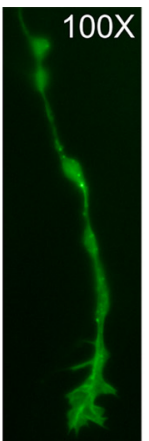

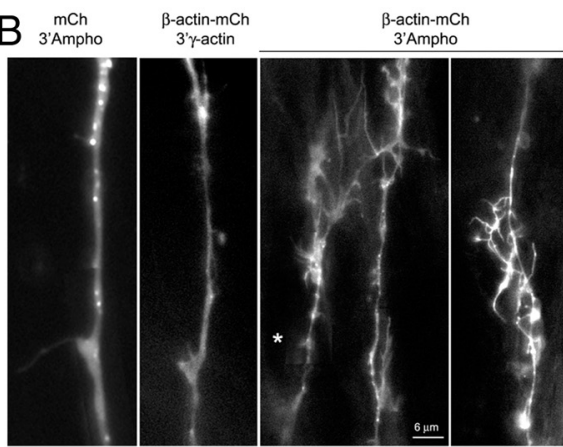

E

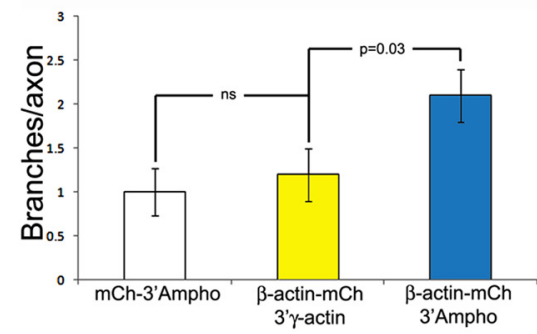

Figure 9. In ovo expression of axonally targeted $\beta$-actin increases axon branching and expression of axonally targeted GAP-43 increases axon length. $\boldsymbol{A}$, Representation of the acute ex vivo spinal cord preparation. DRGs are electroporated in ovo at E3. At E7, the spinal cord is then rapidly dissected from the embryo in its entirety caudal to the first rib and immediately placed into an imaging chamber (left) and imaged. This allows imaging of transfected axons at $20 \times$ and $100 \times$ (middle and right, respectively). $\boldsymbol{B}$, Examples of the morphology of axons in the dorsal funiculi of E7 ex vivo spinal cords imaged at $100 \times$ expressing the denoted construct. Due to the 3D nature of the path of axons through the cord tissue, some features of the axons were best presented pictorially by overlaying segments of images of the same axon from different $z$ levels (e.g., region marked by *). C, Graph showing the number of axonal filopodia per distal axon. The number of axons sampled from four to five spinal cords per group is shown in the bars. These sample sizes apply to $\boldsymbol{D}$ and $\boldsymbol{E}$. $\boldsymbol{D}$, Graph showing the percentage of distal axons (distal $40 \mu \mathrm{m}$ ) that exhibited one or more branches. Raw categorical data were analyzed with a $\chi^{2}$ test, the data are shown as percentage. $\boldsymbol{E}$, Graph showing the mean number of branches per distal axon. Only axons with branches were included in this analysis. $\boldsymbol{F}$, Montages of $20 \times$ images used to reconstruct the extent of axon elongation into the spinal cord measured from the first rib to the caudal most distance axons could be detected. The mean distance axons elongated into the cord are shown, $n=$ number of spinal cords. (Indicated $p$ values were calculated by Mann-Whitney tests in $\boldsymbol{C}, \boldsymbol{E}$, and $\boldsymbol{F}$ and by $\chi^{2}$ test in $\boldsymbol{D}$ ).

The axonal translation of GAP-43 mRNA appears to contribute to elongating axonal growth as injury-conditioned neurons exhibit. Although GAP-43 has long been heralded as a "growthassociated protein" based on its induction during periods of axonal growth and enrichment in growth cones (Benowitz and Routtenberg, 1997), the exact function of GAP-43 is not clear. GAP $-43^{-1-}$ mice showed altered axonal pathfinding arguing that the GAP43 protein has a functional role in the growth of axons (Strittmatter et al., 1995; Kruger et al., 1998; Maier et al., 1999). Nonetheless, rescue experiments that include the axonally localizing GAP-43 mRNA as we performed here were not attempted. It is possible that loss of the GAP-43 gene could alter transport of other mRNAs into axons and contribute to the phenotype of GAP- $43^{-1-}$ animals. Transgenic overexpression of GAP-43 caused only modest effects on axon growth from DRG neurons and did not support regeneration in the CNS leading to the conclusion that GAP-43 is not sufficient to enhance growth on its own (Bomze et al., 2001). However, the 3'UTR that we show drives localization of GAP-43 mRNA was not included in the transgene for these GAP-43 overexpressing animals. We similarly see only modest effects when overexpressing GAP-43, unless the mRNA is targeted into the axons. In our hands, the axonally targeted GAP-43 mRNA rescued the axonal growth deficits seen both with overall depletion of GAP-43 mRNA and with selective depletion of GAP-43 mRNA from axons. We have used two different axonal targeting RNA motifs to show that axonally generated GAP-43 enhances axonal growth. Though we cannot completely exclude the possibility that this axonally targeted GAP-43 mRNA alters transport of other mRNAs into axons, our data suggest that GAP-43 is sufficient to increase axonal outgrowth on its own if the protein is locally synthesized in axons. Considering that GAP-43 mRNA competes with $\beta$-actin for localization, it is intriguing to speculate that increase in axonal transport of $\beta$-actin mRNA might contribute to some of the axonal growth deficits seen in GAP- $43^{-1-}$ mice. Indeed, Maier et al. (1999) showed altered axon growth into barrel cortex in the GAP- $43^{-/-}$mice with irregular clustering of thalamocortical afferents (Maier et al., 1999).

Interestingly, expressing GFP ${ }^{\text {myr }}$ with the $3^{\prime}$ UTR of GAP-43 mRNA does not deplete axons of $\beta$-actin mRNA to the same extent as the $\mathrm{GFP}^{\mathrm{myr}} 3^{\prime} \beta$-actin depletes axons of endogenous $\beta$-actin mRNA. Indeed, the depletion of axonal $\beta$-actin mRNA by GFP ${ }^{\text {myr }} 3^{\prime}$ GAP43 was comparable to the axonal GAP-43 mRNA depletion that we previously saw with expression of 
GFP $^{\text {myr }} 3^{\prime} \beta$-actin (Donnelly et al., 2011). This suggests that GAP-43 mRNA and $\beta$-actin mRNA have different affinities for binding to ZBP1, which could impact the extent to which GAP-43 mRNA can localize into axons following injury. Phosphorylation of ZBP1 decreases its affinity for binding to mRNA (Hüttelmaier et al., 2005), and ZBP1 can clearly bind to many different mRNAs (Jønson et al., 2007). However, ZBP1's affinity for binding to different mRNAs has not been tested. The relative affinities for ZBP1 binding would clearly be a determinant in how much a given mRNA can localize subcellularly and the effect that altered levels of that transcript could have upon other transported mRNAs. This could contribute to the variability in branching deficits seen with introduction of the GFP ${ }^{\text {myr }} 3^{\prime}$ GAP43 construct seen in Figure 7. Interactions with other proteins associated with mRNA-protein complexes could also alter the relative affinity for ZBP1 binding to GAP-43 and $\beta$-actin mRNAs. The Elav protein $\mathrm{HuD}$ binds to an adenine-rich element in GAP-43's 3'UTR (Chung et al., 1997; Mobarak et al., 2000). Based on mRNA coimmunoprecipitation assays, $\mathrm{HuD}$ can also bind to many different transcripts (Bolognani et al., 2010), and HuD and the human ortholog of ZBP1, IMP1, have been copurified with the RNA localization element of Tau mRNA (Atlas et al., 2004). Thus, there is precedent for such a complex of RNA binding proteins, but it is not clear if this occurs with $\beta$-actin or GAP-43 mRNAs. Nonetheless, recent work from the Sahin lab has linked $\mathrm{HuD}$ to axonal transport of Neuritin/cpg15 mRNA in cortical neurons (Akten et al., 2011). Future work will be needed to determine the exact composition of RNA-protein complexes transporting $\beta$-actin and GAP-43 mRNA into axons.

In conclusion, this work indicates that the axonal translation of $\beta$-actin and GAP-43 mRNAs have differential roles in the development of axonal morphogenesis. The use of disparate 3'UTRs (e.g., Amph and Stat $3 \alpha^{\text {long }}$ ) to target and drive the axonal translation of mRNAs of interest represents a novel strategy for the analysis of the functions of axonal translation. In the future, it will be of interest to determine the roles of axonally targeted ORFs, using this approach, in axon regeneration.

\section{References}

Akten B, Kye MJ, Hao le T, Wertz MH, Singh S, Nie D, Huang J, Merianda TT, Twiss JL, Beattie CE, Steen JA, Sahin M (2011) Interaction of survival of motor neuron (SMN) and HuD proteins with mRNA cpg15 rescues motor neuron axonal deficits. Proc Natl Acad Sci U S A 108:10337-10342. CrossRef Medline

Andreassi C, Zimmermann C, Mitter R, Fusco S, De Vita S, Saiardi A, Riccio A (2010) An NGF-responsive element targets myo-inositol monophosphatase-1 mRNA to sympathetic neuron axons. Nat Neurosci 13:291-301. CrossRef Medline

Atlas R, Behar L, Elliott E, Ginzburg I (2004) The insulin-like growth factor mRNA binding-protein IMP-1 and the Ras-regulatory protein G3BP associate with tau mRNA and HuD protein in differentiated P19 neuronal cells. J Neurochem 89:613-626. CrossRef Medline

Benowitz LI, Routtenberg A (1997) GAP-43: an intrinsic determinant of neuronal development and plasticity. Trends Neurosci 20:84-91. CrossRef Medline

Ben-Tov Perry R, Doron-Mandel E, Iavnilovitch E, Rishal I, Dagan SY, Tsoory M, Coppola G, McDonald MK, Gomes C, Geschwind DH, Twiss JL, Yaron A, Fainzilber M (2012) Subcellular knockout of importin $\beta 1$ perturbs axonal retrograde signaling. Neuron 75:294-305. CrossRef Medline

Ben-Yaakov K, Dagan SY, Segal-Ruder Y, Shalem O, Vuppalanchi D, Willis DE, Yudin D, Rishal I, Rother, F, Bader M, Blesch A, Pilpel Y, Twiss JL, Fainzilber M (2012) Axonal Transcription Factors Signal Retrogradely In Lesioned Peripheral Nerve. EMBO J 31:1350-1363. CrossRef Medline

Bolognani F, Contente-Cuomo T, Perrone-Bizzozero NI (2010) Novel recognition motifs and biological functions of the RNA-binding protein
$\mathrm{HuD}$ revealed by genome-wide identification of its targets. Nucleic Acids Res 38:117-130. Medline

Bomze HM, Bulsara KR, Iskandar BJ, Caroni P, Skene JH (2001) Spinal axon regeneration evoked by replacing two growth cone proteins in adult neurons. Nat Neurosci 4:38-43. CrossRef Medline

Cajigas IJ, Tushev G, Will TJ, tom Dieck S, Fuerst N, Schuman EM (2012) The local transcriptome in the synaptic neuropil revealed by deep sequencing and high-resolution imaging. Neuron 74:453-466. CrossRef Medline

Cheever TR, Olson EA, Ervasti JM (2011) Axonal regeneration and neuronal function are preserved in motor neurons lacking ss-actin in vivo. PLoS One 6:e17768. CrossRef Medline

Cheever TR, Li B, Ervasti JM (2012) Restricted morphological and behavioral abnormalities following ablation of beta-actin in the brain. PLoS One 7:e32970. CrossRef Medline

Chung S, Eckrich M, Perrone-Bizzozero N, Kohn DT, Furneaux H (1997) The Elav-like proteins bind to a conserved regulatory element in the 3'-untranslated region of GAP-43 mRNA. J Biol Chem 272:6593-6598. CrossRef Medline

Cox LJ, Hengst U, Gurskaya NG, Lukyanov KA, Jaffrey SR (2008) Intraaxonal translation and retrograde trafficking of CREB promotes neuronal survival. Nat Cell Biol 10:149-159. CrossRef Medline

Donnelly CJ, Willis DE, Xu M, Tep C, Jiang C, Yoo S, Schanen NC, KirnSafran CB, van Minnen J, English A, Yoon SO, Bassell GJ, Twiss JL (2011) Limited availability of ZBP1 restricts axonal mRNA localization and nerve regeneration capacity. EMBO J 30:4665-4677. CrossRef Medline

Eng H, Lund K, Campenot RB (1999) Synthesis of beta-tubulin, actin, and other proteins in axons of sympathetic neurons in compartmented cultures. J Neurosci 19:1-9. Medline

Gallo G (2011) The cytoskeletal and signaling mechanisms of axon collateral branching. Dev Neurobiol 71:201-220. CrossRef Medline

Gumy LF, Yeo GS, Tung YC, Zivraj KH, Willis D, Coppola G, Lam BY, Twiss JL, Holt CE, Fawcett JW (2011) Transcriptome analysis of embryonic and adult sensory axons reveals changes in mRNA repertoire localization. RNA 17:85-98. CrossRef Medline

Hanz S, Perlson E, Willis D, Zheng JQ, Massarwa R, Huerta JJ, Koltzenburg M, Kohler M, van-Minnen J, Twiss JL, Fainzilber M (2003) Axoplasmic importins enable retrograde injury signaling in lesioned nerve. Neuron 40:1095-1104. CrossRef Medline

Hoffman PN (2010) A conditioning lesion induces changes in gene expression and axonal transport that enhance regeneration by increasing the intrinsic growth state of axons. Exp Neurol 223:11-18. CrossRef Medline

Holt CE, Bullock SL (2009) Subcellular mRNA localization in animal cells and why it matters. Science 326:1212-1216. CrossRef Medline

Hüttelmaier S, Zenklusen D, Lederer M, Dictenberg J, Lorenz M, Meng X, Bassell GJ, Condeelis J, Singer RH (2005) Spatial regulation of betaactin translation by Src-dependent phosphorylation of ZBP1. Nature 438 : 512-515. CrossRef Medline

Jønson L, Vikesaa J, Krogh A, Nielsen LK, Hansen Tv, Borup R, Johnsen AH, Christiansen J, Nielsen FC (2007) Molecular composition of IMP1 ribonucleoprotein granules. Mol Cell Proteomics 6:798-811. CrossRef Medline

Ketschek A, Gallo G (2010) Nerve growth factor induces axonal filopodia through localized microdomains of phosphoinositide 3-kinase activity that drive the formation of cytoskeletal precursors to filopodia. J Neurosci 30:12185-12197. CrossRef Medline

Kruger K, Tam AS, Lu C, Sretavan DW (1998) Retinal ganglion cell axon progression from the optic chiasm to initiate optic tract development requires cell autonomous function of GAP-43. J Neurosci 18:5692-5705. Medline

Leung KM, van Horck FP, Lin AC, Allison R, Standart N, Holt CE (2006) Asymmetrical beta-actin mRNA translation in growth cones mediates attractive turning to netrin-1. Nat Neurosci 9:1247-1256. CrossRef Medline

Lyles V, Zhao Y, Martin KC (2006) Synapse formation and mRNA localization in cultured Aplysia neurons. Neuron 49:349-356. CrossRef Medline

Maier DL, Mani S, Donovan SL, Soppet D, Tessarollo L, McCasland JS, Meiri KF (1999) Disrupted cortical map and absence of cortical barrels in growth-associated protein (GAP)-43 knockout mice. Proc Natl Acad Sci U S A 96:9397-9402. CrossRef Medline

Manns RP, Cook GM, Holt CE, Keynes RJ (2012) Differing semaphorin 3A 
concentrations trigger distinct signaling mechanisms in growth cone collapse. J Neurosci 32:8554-8559. CrossRef Medline

Michaelevski I, Segal-Ruder Y, Rozenbaum M, Medzihradszky KF, Shalem O, Coppola G, Horn-Saban S, Ben-Yaakov K, Dagan SY, Rishal I, Geschwind DH, Pilpel Y, Burlingame AL, Fainzilber M (2010) Signaling to transcription networks in the neuronal retrograde injury response. Sci Signal 3:ra53. CrossRef Medline

Mili S, Moissoglu K, Macara IG (2008) Genome-wide screen reveals APCassociated RNAs enriched in cell protrusions. Nature 453:115-119. CrossRef Medline

Mobarak CD, Anderson KD, Morin M, Beckel-Mitchener A, Rogers SL, Furneaux H, King P, Perrone-Bizzozero NI (2000) The RNA-binding protein $\mathrm{HuD}$ is required for GAP-43 mRNA stability, GAP-43 gene expression, and PKC-dependent neurite outgrowth in PC12 cells. Mol Biol Cell 11:3191-3203. Medline

Roche FK, Marsick BM, Letourneau PC (2009) Protein synthesis in distal axons is not required for growth cone responses to guidance cues. J Neurosci 29:638-652. CrossRef Medline

Sasaki Y, Welshhans K, Wen Z, Yao J, Xu M, Goshima Y, Zheng JQ, Bassell GJ (2010) Phosphorylation of zipcode binding protein 1 is required for brain-derived neurotrophic factor signaling of local beta-actin synthesis and growth cone turning. J Neurosci 30:9349-9358. Medline

Shestakova EA, Singer RH, Condeelis J (2001) The physiological significance of beta-actin mRNA localization in determining cell polarity and directional motility. Proc Natl Acad Sci U S A 98:7045-7050. CrossRef Medline

Skene JH, Jacobson RD, Snipes GJ, McGuire CB, Norden JJ, Freeman JA (1986) A protein induced during nerve growth (GAP-43) is a major component of growth-cone membranes. Science 233:783-786. CrossRef Medline

Smith DS, Skene JH (1997) A transcription-dependent switch controls competence of adult neurons for distinct modes of axon growth. J Neurosci 17:646-658. Medline

Spillane M, Ketschek A, Jones SL, Korobova F, Marsick B, Lanier L, Svitkina T, Gallo G (2011) The actin nucleating Arp2/3 complex contributes to the formation of axonal filopodia and branches through the regulation of actin patch precursors to filopodia. Dev Neurobiol 71:747-758. CrossRef Medline

Spillane M, Ketschek A, Donnelly CJ, Pacheco A, Twiss JL, Gallo G (2012) Nerve growth factor-induced formation of axonal filopodia and collateral branches involves the intra-axonal synthesis of regulators of the actin nucleating Arp2/3 complex. J Neurosci 32:17671-17689. CrossRef Medline

Strittmatter SM, Fankhauser C, Huang PL, Mashimo H, Fishman MC (1995) Neuronal pathfinding is abnormal in mice lacking the neuronal growth cone protein GAP-43. Cell 80:445-452. CrossRef Medline

Taylor AM, Berchtold NC, Perreau VM, Tu CH, Li Jeon N, Cotman CW (2009) Axonal mRNA in uninjured and regenerating cortical mammalian axons. J Neurosci 29:4697-4707. CrossRef Medline

Twiss JL, Smith DS, Chang B, Shooter EM (2000) Translational control of ribosomal protein $\mathrm{L} 4$ is required for rapid neurite extension. Neurobiol Dis 7:416-428. CrossRef Medline

Vuppalanchi D, Coleman J, Yoo S, Merianda TT, Yadhati AG, Hossain J, Blesch A, Willis DE, Twiss JL (2010) Conserved 3'-untranslated region sequences direct subcellular localization of chaperone protein mRNAs in neurons. J Biol Chem 285:18025-18038. CrossRef Medline

Willis DE, van Niekerk EA, Sasaki Y, Mesngon M, Merianda TT, Williams GG, Kendall M, Smith DS, Bassell GJ, Twiss JL (2007) Extracellular stimuli specifically regulate localized levels of individual neuronal mRNAs. J Cell Biol 178:965-980. CrossRef Medline

Willis D, Li KW, Zheng JQ, Chang JH, Smit AB, Smit A, Kelly T, Merianda TT, Sylvester J, van Minnen J, Twiss JL (2005) Differential transport and local translation of cytoskeletal, injury-response, and neurodegeneration protein mRNAs in axons. J Neurosci 25:778-791. CrossRef Medline

Yao J, Sasaki Y, Wen Z, Bassell GJ, Zheng JQ (2006) An essential role for beta-actin mRNA localization and translation in $\mathrm{Ca}(2+)$-dependent growth cone guidance. Nat Neurosci 9:1265-1273. CrossRef Medline

Zhang HL, Eom T, Oleynikov Y, Shenoy SM, Liebelt DA, Dictenberg JB, Singer RH, Bassell GJ (2001) Neurotrophin-induced transport of a betaactin mRNP complex increases beta-actin levels and stimulates growth cone motility. Neuron 31:261-275. CrossRef Medline

Zheng JQ, Kelly TK, Chang B, Ryazantsev S, Rajasekaran AK, Martin KC, Twiss JL (2001) A functional role for intra-axonal protein synthesis during axonal regeneration from adult sensory neurons. J Neurosci 21:92919303. Medline

Zivraj KH, Tung YC, Piper M, Gumy L, Fawcett JW, Yeo GS, Holt CE (2010) Subcellular Profiling Reveals Distinct and Developmentally Regulated Repertoire of Growth Cone mRNAs. J Neurosci 30:1546415478. CrossRef Medline 